\title{
Article
}

\section{Carbon Dots/Iron Oxide Nanoparticles with Tuneable Composition and Properties}

Stachowska, Joanna, Gamza, Monika, Mellor, Claire, Gibbons, Ella Nicole, Krysmann, Marta, Kelarakis, Antonios, GumieniczekChłopek, Elżbieta, Strączek, Tomasz, Kapusta, Czesław and Szwajca, Anna

Available at http://clok.uclan.ac.uk/40751/

Stachowska, Joanna, Gamza, Monika ORCID: 0000-0003-3360-4006, Mellor, Claire ORCID: 0000-0002-7647-2085, Gibbons, Ella Nicole, Krysmann, Marta ORCID: 0000-0002-8036-4925, Kelarakis, Antonios ORCID: 0000-0002-81125176, Gumieniczek-Chłopek, Elżbieta, Strączek, Tomasz, Kapusta, Czesław et al (2022) Carbon Dots/Iron Oxide Nanoparticles with Tuneable Composition and Properties. Nanomaterials, 12 (4). e674.

It is advisable to refer to the publisher's version if you intend to cite from the work. http://dx.doi.org/10.3390/nano12040674

For more information about UCLan's research in this area go to http://www.uclan.ac.uk/researchgroups/ and search for <name of research Group>.

For information about Research generally at UCLan please go to http://www.uclan.ac.uk/research/

All outputs in CLoK are protected by Intellectual Property Rights law, including Copyright law. Copyright, IPR and Moral Rights for the works on this site are retained by the individual authors and/or other copyright owners. Terms and conditions for use of this material are defined in the policies page. 


\title{
Article \\ Carbon Dots/Iron Oxide Nanoparticles with Tuneable Composition and Properties
}

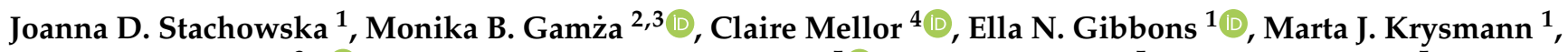 \\ Antonios Kelarakis ${ }^{3, *}{ }^{\circledR}$, Elżbieta Gumieniczek-Chłopek ${ }^{5}{ }^{(D}$, Tomasz Strączek ${ }^{5}$, Czesław Kapusta ${ }^{5}$ \\ and Anna Szwajca ${ }^{6}$ (D)
}

1 School of Dentistry, University of Central Lancashire, Preston PR1 2HE, UK; jstachowska@uclan.ac.uk (J.D.S.); engibbons3@uclan.ac.uk (E.N.G.); mkrysmann@uclan.ac.uk (M.J.K.)

2 Jeremiah Horrocks Institute for Mathematics, Physics, and Astrophysics, University of Central Lancashire, Preston PR1 2HE, UK; mgamza@uclan.ac.uk

3 UCLan Research Centre for Smart Materials, School of Natural Sciences, University of Central Lancashire, Preston PR1 2HE, UK

4 School of Phycology and Computer Science, University of Central Lancashire, Preston PR1 2HE, UK; cmellor3@uclan.ac.uk

5 Faculty of Physics and Applied Computer Science, AGH University of Science and Technology, Mickiewicza Ave. 30, 30-059 Krakow, Poland; echlopek@agh.edu.pl (E.G.-C.); tomasz.straczek@fis.agh.edu.pl (T.S.); kapusta@agh.edu.pl (C.K.)

6 Faculty of Chemistry, Adam Mickiewicz University, Umultowska 89b, 61-614 Poznań, Poland; anna.szwajca@amu.edu.pl

* Correspondence: akelarakis@uclan.ac.uk; Tel.: +44-017-724-172

\section{check for}

updates

Citation: Stachowska, J.D.; Gamża, M.B.; Mellor, C.; Gibbons, E.N.;

Krysmann, M.J.; Kelarakis, A.; Gumieniczek-Chłopek, E.; Strączek, T.; Kapusta, C.; Szwajca, A. Carbon Dots/Iron Oxide Nanoparticles with Tuneable Composition and Properties. Nanomaterials 2022, 12, 674. https://doi.org/10.3390/ nano12040674

Academic Editor: Marco Cannas

Received: 5 January 2022

Accepted: 14 February 2022

Published: 17 February 2022

Publisher's Note: MDPI stays neutral with regard to jurisdictional claims in published maps and institutional affiliations.

Copyright: (c) 2022 by the authors. Licensee MDPI, Basel, Switzerland. This article is an open access article distributed under the terms and conditions of the Creative Commons Attribution (CC BY) license (https:// creativecommons.org/licenses/by/ $4.0 /)$.

\begin{abstract}
We present a simple strategy to generate a family of carbon dots/iron oxide nanoparticles (C/Fe-NPs) that relies on the thermal decomposition of iron (III) acetylacetonate in the presence of a highly fluorescent carbon-rich precursor (derived via thermal treatment of ethanolamine and citric acid at $180^{\circ} \mathrm{C}$ ), while polyethylene glycol serves as the passivation agent. By varying the molar ratio of the reactants, a series of $\mathrm{C} / \mathrm{Fe}-\mathrm{NPs}$ have been synthesized with tuneable elemental composition in terms of $\mathrm{C}, \mathrm{H}, \mathrm{O}, \mathrm{N}$ and $\mathrm{Fe}$. The quantum yield is enhanced from 6 to $9 \%$ as the carbon content increases from 27 to $36 \mathrm{wt} \%$, while the room temperature saturation magnetization is improved from 4.1 to $17.7 \mathrm{emu} / \mathrm{g}$ as the iron content is enriched from 17 to $31 \mathrm{wt} \%$. In addition, the C/Fe-NPs show excellent antimicrobial properties, minimal cytotoxicity and demonstrate promising bioimaging capabilities, thus showing great potential for the development of advanced diagnostic tools.
\end{abstract}

Keywords: magnetization; photoluminescence; carbon dots; magnetic nanoparticles; antimicrobial

\section{Introduction}

Superparamagnetic iron oxide nanoparticles (Fe-NPs) with sizes below $20 \mathrm{~nm}$ have been widely explored in a wide range of biomedical applications, including magnetically controlled gene and drug delivery [1,2], hyperthermia treatment [3], bioseparation of cells [4], cell tracking and tissue repair [1], magnetic resonance imaging (MRI) [5,6], biosensors [7], diagnosis and treatment of bacterial infections [8]. Common strategies for the preparation of Fe-NPs rely on thermal decomposition [9], coprecipitation [10,11], sol-gel methods [12], hydrothermal and solvothermal treatment of iron-rich precursors [5]. Accurate control of the reaction conditions (nature of organometallic reactants, iron salts, surfactants, solvents, temperature, duration), purification protocols and passivation strategies can lead to tailor-made Fe-NPs with narrow size distribution [13].

Given that Fe-NPs are susceptible to oxidation and are particularly prone to agglomeration, surface protection and passivation strategies are essential to impart long-term structural and colloidal stability. To that end, surfactants and macromolecules are physically adsorbed or chemically attached to Fe-NPs, while passivating layers based on precious 
metals, silica and carbon can accommodate various functional groups, facilitating further conjugation with ligands, biomolecules and nanostructures. An expanding body of literature focuses on Fe-NPs combined with peptides [14], DNA [15], aptamers [16], lipids [17], drug molecules [18], biopolymers [19], dendrimers [20], rare earth elements [21], metal organic frameworks [22], graphene oxide [23], carbon nanotubes [24] and fullerenes [25].

Particular emphasis is given to the development of hybrid materials based on FeNPs that exhibit fluorescent properties stemming from the presence of organic dyes [26], quantum dots [27], graphene quantum dots [28] and carbon dots (C-dots) [29]. Heteroatom doping can alter the electronic and optical properties of C-dots, oftentimes giving rise to red-shifted emissive systems [30]. In particular, hybrid nanoparticles composed of Fe-NPs and C-dots (C/Fe-NPs) combine the supreme magnetic properties of Fe-NPs with the excellent photoluminescent behavior and non-toxic nature of C-dots [31,32] and are ideal candidates for photothermal therapy [33], optical bioimaging [34], dual-modal bioimaging [35], bacteria sensing [36] and antimicrobial treatment [37]. Although, a number of interesting approaches have been proposed for the synthesis of C/Fe-NPs [16,29,36,38-44], the development of environmentally benign, cost and time effective synthetic strategies yielding a versatile range of $\mathrm{C} / \mathrm{Fe}-\mathrm{NPs}$ remains an open challenge.

In this study we demonstrate a facile method to fine-tune the chemical composition and, thereby, the optical and magnetic properties of $\mathrm{C} / \mathrm{Fe}-\mathrm{NPs}$, thus generating a novel family of multifunctional nanomaterials. We present a simple strategy to synthesize a series of $\mathrm{C} / \mathrm{Fe}-\mathrm{NPs}$ with varying chemical composition that exhibit tuneable magnetization coupled with superior wavelength-dependent optical properties, bioimaging capabilities, non-toxic nature and antimicrobial activity.

\section{Materials and Methods}

\subsection{Materials}

Iron (III) acetylacetonate $\geq 99.9 \%$ trace metal basis $\left(\mathrm{Fe}(\mathrm{acac})_{3}\right)$ and ethanolamine $\geq 98 \%$ (EA) were purchased from Sigma Aldrich. Polyethylene glycol $400\left(\mathrm{PEG}_{400}\right)$, citric acid monohydrate $99.5 \%$ (CA), propan-2-ol 99\% and diphenyl ether 99.5\% were obtained from Alfa Aesar.

\subsection{Synthesis of Magnetic C-Dots}

Magnetic C-dots were synthesized by thermal decomposition of iron and carbon precursors dispersed in the high boiling point solvent diphenyl ether, as presented in Scheme 1.

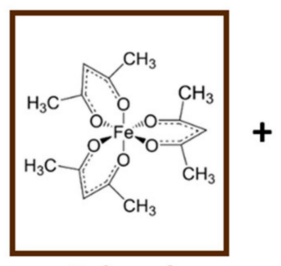

$\mathrm{Fe}(\mathrm{acac})_{3}$

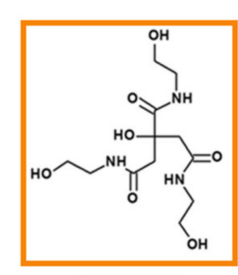

CNP180

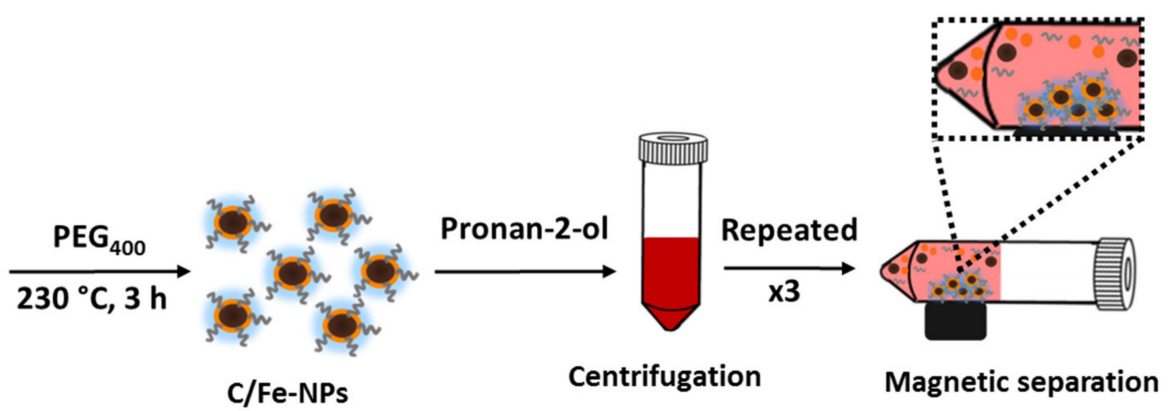

C/Fe-NPs

Scheme 1. Schematic representation of the process followed for the synthesis of C-Fe/NPs.

A highly photoluminescent C-dots precursor (CNP180) was synthesized via thermal treatment of CA and EA (molar ratio 3:1) at $180^{\circ} \mathrm{C}$, in accordance with a previously reported method [45]. Subsequently, various amounts of CNP180 (0.36 g, $0.45 \mathrm{~g}, 0.54 \mathrm{~g}, 0.63 \mathrm{~g}, 1.08 \mathrm{~g})$ were added into $0.72 \mathrm{~g}$ of iron (III) acetylacetonate along with $7.5 \mathrm{mmol}$ of polyethylene glycol 400 and $20 \mathrm{~mL}$ of diphenyl ether. Subsequently, the mixture of precursors was heated under reflux with constant stirring for $3 \mathrm{~h}$ at $230^{\circ} \mathrm{C}$, to facilitate the formation of 
an amorphous coating of CNP230 on the iron oxide-based centers. The precipitate was purified by adding $40 \mathrm{~mL}$ of propan-2-ol to the mixture, followed by centrifugation at $8000 \mathrm{rpm}$ for $10 \mathrm{~min}$ and this step was repeated three times. The C/Fe-NPs thus received were dispersed in distilled water, left for $15 \mathrm{~min}$ with a magnet attached to the vial's wall and the particles not attracted by the magnet were discarded. Finally, all samples were freeze-dried and afterwards stored under ambient conditions.

\subsection{Characterization}

Elemental analysis was conducted with a CHNS Elemental Analyzer (Flash 2000, Thermo Fisher Scientific, Waltham, MA, USA) equipped with a column for oxygen determination that was calibrated against 2,5-(Bis(5-tert-butyl-2-benzo-oxazol-2-yl)thiophene (Thermo Fisher Scientific, Waltham, MA, USA). The carbon, hydrogen, nitrogen analysis was carried out in aluminum pans, while oxygen analysis in silver pans (both types of pans were received from CE Instruments).

Magnetization curves of the solid samples were obtained at temperatures of 296 and $70 \mathrm{~K}$ by using a low temperature Faraday balance magnetometer with a continuous flow cryostat. More detailed magnetic measurements were carried out on selected samples at the VSM option of the Quantum Design PPMS apparatus (San Diego, CA, USA) with the oscillation frequency of $40 \mathrm{~Hz}$ in the temperature range from 4 to $300 \mathrm{~K}$. The zero field cooled (ZFC) and field cooled (FC) magnetic susceptibility curves were measured in the magnetic field of 100 Oe. The FC data was collected on cooling the nanoparticles in the desired field, whereas the ZFC magnetic susceptibilities were measured after cooling the samples in zero applied field to $4 \mathrm{~K}$, then applying the magnetic field of 100 Oe and recording the data while slowly warming the nanoparticles up to $300 \mathrm{~K}$. Mass magnetization and magnetic susceptibility values were calculated per gram of $\mathrm{Fe}_{3-\delta} \mathrm{O}_{4}$ with error bars accounting for uncertainties in the stoichiometry $(0 \leq \delta \leq 0.33)$ and the measured Fe content.

Transmission electron microscopy (TEM) images were recorded by the FEI Tecnai T12 Spirit TEM (FEI company, Hillsboro, OR, USA) operated at $120 \mathrm{kV}$. A droplet of $0.05 \mathrm{mg} / \mathrm{mL}$ $\mathrm{C} / \mathrm{Fe}-\mathrm{NPs}$ in water was allowed to dry on a carbon coated cupper grid (Agar Scientific, Stansted, UK) and dried under air. The size histogram has been plotted on the basis of 395 fields using a suitable software.

Fourier transform infrared (FTIR) spectra were obtained by Nicolet IS5 spectrometer (Thermo Fisher Scientific, Waltham, MA, USA) within the range of $4000-500 \mathrm{~cm}^{-1}$. For each measurement, the samples were scanned 128 times at a resolution of $2 \mathrm{~cm}^{-1}$.

Powder X-ray diffraction (PXRD) patterns were recorded by Bruker D2 Phaser diffractometer (Billerica, MA, USA) equipped with a Lynxeye 1-dimensional detector using $\mathrm{Cu}$ $\mathrm{K} \alpha$ radiation. Similar volumes of $\mathrm{C} / \mathrm{Fe}-\mathrm{NPs}$ were scanned for $60 \mathrm{~min}$ in the $2 \theta$ range of 5-80 . Le Bail refinements of the PXRD patterns were carried out with Jana2006 [46]. Bragg peaks were fitted using Lorentzian profiles, and the variation of the half-widths with Bragg angle $\theta$ was described by $H_{\mathrm{L}}(\theta)=X / \cos \theta+\Gamma \mathrm{L}(\theta)$. Here, the first term accounts for isotropic Scherrer broadening due to limited size of diffracting crystallites, while the second term describes instrumental broadening. The latter was assessed from PXRD pattern of high-purity $(6 \mathrm{~N})$ germanium powder with controlled grain size. Thus, after subtracting the instrumental broadening, the volume averaged size of crystallites was calculated from refined $X$ values in degrees using the formula: $D_{\mathrm{V}}=360 K_{S} \lambda /(\pi 2 X)$, where $\lambda$ is the wavelength of the radiation used for the diffraction study, and $K_{S}$ denoting the Scherrer constant was assumed to be 1 [47], providing lower bounds for mean sizes of diffracting grains as other contributions to peak broadening (e.g., due to microstrain) were not considered.

Thermogravimetric analysis (TGA) measurements were carried out using a TGAQ500 instrument (TA Instruments, New Castle, UK). Samples were heated over the range of $25-500{ }^{\circ} \mathrm{C}$ at a heating rate of $10{ }^{\circ} \mathrm{C} / \mathrm{min}$, under continuous nitrogen flow.

Ultraviolet-visible (UV-Vis) spectra of aqueous dispersions of C/Fe-NPs placed in Hellma Analytics quartz cuvette with $1.0 \mathrm{~cm}$ pathlength were recorded at room temperature by means of a UV-3600 spectrophotometer (Shimadzu, Torrance, CA, USA). 
Photoluminescence (PL) spectra of aqueous dispersions of C/Fe-NPs were collected under excitation wavelengths between 275 and $500 \mathrm{~nm}$ using a Horiba Fluoromax spectrofluorometer (Kyoto, Japan) and the samples were placed in Hellma Analytics quartz cuvette with $1.0 \mathrm{~cm}$ pathlength.

The quantum yields (QY) of C/Fe-NPs dispersions were determined using anthracene (Sigma Aldrich, Saint Louis, MO, USA) with $\mathrm{QY}_{\mathrm{R}}=0.27$ at $\lambda_{\mathrm{ex}}=365 \mathrm{~nm}$ as a standard reference dye and calculated from the equation:

$$
\mathrm{QY}=\mathrm{QY}_{\mathrm{R}} \times\left(\frac{\mathrm{I}}{\mathrm{I}_{\mathrm{R}}}\right) \times\left(\frac{\mathrm{A}_{\mathrm{R}}}{\mathrm{A}}\right) \times\left(\frac{\eta^{2}}{\eta_{\mathrm{R}}^{2}}\right)
$$

where I refers to the integrated fluorescence intensity of the tested material, A refers to its absorbance value and $\eta$ is the refractive index of the solvent. The subscript $R$ indicates the reference dye. The dye anthracene was dissolved in ethanol $(\eta=1.36)$ while the examined samples were dispersed in ultra-pure water $\left(\eta_{R}=1.33\right)$. To minimize re-absorption effects, absorbance values were kept below 0.10 .

Photoluminescence lifetime decays were measured by Edinburgh Instruments LifeSpecII (Livingston, UK) using two pulsed diode lasers operating at $450 \mathrm{~nm}$ (EPL-450) and $375 \mathrm{~nm}$ (EPL-375). Time-correlated single photon counting (TCSPC) data acquisition unit processed the detector signals. The PL lifetime decays were recorded with 10,000 peak counts for the aqueous solutions transferred into quartz cuvette $(1 \mathrm{~cm}$ pathlength) at room temperature over $200 \mathrm{~ns}$ time range. The same parameters were kept for recording the instrument response function (IRF), while using dilute aqueous suspension of silica (Ludox HS-30, Sigma Aldrich). The average PL lifetimes $\left(\tau_{\mathrm{avg}}\right)$ were calculated from the equation:

$$
\tau_{\mathrm{avg}}=\frac{\sum \alpha_{i} \tau_{i}^{2}}{\sum \alpha_{i} \tau_{i}}
$$

where $\tau_{i}$ is the time component of multiexponential decay fitting and $\alpha_{i}$ is the fractional weight for each time component.

X-ray photoelectron spectroscopy (XPS) was performed using SPECS spectrometer (Berlin, Germany) equipped with $\mathrm{Al} \mathrm{K} \alpha$ X-ray radiation source (emitting photons 1486.64 $\mathrm{eV}$ ) and a PHOIBOS 150 (hemispherical analyzer) with the 20-eV pass energy. The base pressure of the XPS system was $2 \times 10^{-8} \mathrm{~Pa}$. CASA XPS software was used to solve the XPS peaks. This was solved by curve fitting with the sum of the lines (Gaussian (70\%) and Lorentzian (30\%)). Secondary electron background was subtracted using the Shirley procedure. The internal calibration of the XPS spectra was done according to a binding energy value of $284.6 \mathrm{eV}$ for C1s peak.

Cytotoxicity of $\mathrm{C} / \mathrm{Fe}-\mathrm{NPs}$ against epithetical HeLa cervix cancer cell line was evaluated by the standard MTT (3-(4,5-dimethylthiazolyl-2)-2,5-diphenyltetrazolium bromide) assay (Sigma Aldrich). The HeLa cells were cultured in Dulbecco's modified Eagle medium (DMEM, Thermo Scientific, Waltham, MA, USA) supplemented with $10 \%$ fetal bovine serum (Thermo Fisher Scientific) and 1\% penicillin-streptomycin $(10,000 \mathrm{U} / \mathrm{mL}$, Thermo Fisher Scientific). At first, $50 \mu \mathrm{L}$ of cell dispersion $\left(1 \times 10^{5}\right.$ cells $\left./ \mathrm{mL}\right)$ were seeded in a 96-well plate and were incubated overnight $\left(37^{\circ} \mathrm{C}, 5 \% \mathrm{CO}_{2}\right)$, so that the cells could adhere to the bottom of the well. Subsequently, the cells were incubated with C/Fe-NPs (10-200 $\mu \mathrm{g} / \mathrm{mL}$ in DMEM) for $24 \mathrm{~h}$. Then, $20 \mu \mathrm{L}$ of $5 \mathrm{mg} / \mathrm{mL}$ MTT solution was transferred into each well and was further incubated for $2 \mathrm{~h}$. Afterwards, $150 \mu \mathrm{L}$ of $0.7 \mathrm{M}$ lysis buffer was added into each well to liquefy the formazan crystals. Finally, the optical density (OD) of tested materials was measured by a microplate reader (Thermo Fisher Scientific, Waltham, MA, USA) with a set up wavelength at $595 \mathrm{~nm}$. Cell viability was determined via the relationship:

$$
\text { Cell viability }(\%)=\frac{\mathrm{OD}_{\text {treated }}}{\mathrm{OD}_{\text {control }}} \times 100
$$


where $\mathrm{OD}_{\text {control }}$ and $\mathrm{OD}_{\text {treated }}$ were recorded in the absence and the presence of $\mathrm{C} / \mathrm{Fe}-\mathrm{NPs}$, respectively. Measurements were performed three times and the mean value was calculated.

In vitro fluorescence imaging was done for the HeLa cells cultured in DMEM in the presence of $10 \%$ FBS $(v / v)$ and $1 \%$ penicillin-streptomycin $(v / v)$ at $37{ }^{\circ} \mathrm{C}\left(5 \% \mathrm{CO}_{2}, 95 \%\right.$ air $)$ for $24 \mathrm{~h}$. Subsequently, liquid dispersions of $50 \mu \mathrm{g} / \mathrm{mL} \mathrm{C} / \mathrm{Fe}-\mathrm{NPs}$ were added into each well with the HeLa cells and incubated for a further $24 \mathrm{~h}$. Afterwards, the media was aspirated and the cells were washed three times using PBS buffer ( $\mathrm{pH} 7.2$ ). The fluorescence imaging in live cells was performed with the use of Zeiss Axio Scope A1 microscope (Oberkochen, Germany), under a bright field, and under excitation wavelengths of 366, 488 and $512 \mathrm{~nm}$.

Antimicrobial studies - the culturing protocol has been reported previously [48]. Briefly, an inoculated nutrient broth with a single loop of either Escherichia coli (E. coli) or Staphylococcus aureus (S. aureus) was incubated for $24 \mathrm{~h}$ at $37^{\circ} \mathrm{C}$, while using SciQuip Incu-Shake MIDI orbital shaker (SciQuip Ltd., Newtown, Wem, Shropshire, UK) set as $200 \mathrm{rpm}$. Afterwards, the bacteria cultures were centrifuged twice, followed by the disposal of supernatant. Then, the cultures were resuspended and further diluted in broth, in order to obtain absorbance values close to a 0.5 McFarlane standard.

The method used for antimicrobial testing required dispersion of $0.1 \mathrm{~g}$ of $\mathrm{C} / \mathrm{Fe}-\mathrm{NPs}$ in $1 \mathrm{~mL}$ nutrient broth, which had to be further autoclaved. Afterwards, $1 \mathrm{~mL}$ of tested bacterial strain and $8 \mathrm{~mL}$ sterile nutrient broth were added into each dispersion and the mixture was incubated for $24 \mathrm{~h}$ at $37^{\circ} \mathrm{C}$ under $200 \mathrm{rpm}$ stirring. Subsequently, $1 \mathrm{~mL}$ aliquot was taken from each suspension and further serially diluted by transferring $100 \mu \mathrm{L}$ of it into $900 \mu \mathrm{L}$ Ringer's solution with $\frac{1}{4}$ strength. The dilution process was repeated until the number of bacterial colonies fell to between 30 and 300. Subsequently, $100 \mu \mathrm{L}$ of each one from the series of diluted suspension was spread onto agar-gelled nutrient plates, with the use of sterile plastic spreader. In the final step, the agar plates were incubated at $37^{\circ} \mathrm{C}$ for $24 \mathrm{~h}$ and the number of bacterial colonies was estimated. The comparison with the control plate allowed calculation of the overall percentage of bacterial colonies decrease accordingly to the following equation:

$$
\text { Bacterial colony decrease }(\%)=\frac{\text { Control }- \text { Test }}{\text { Control }} \times 100
$$

Measurements for each of the C/Fe-NPs were performed three times and their mean values are reported.

\section{Results and Discussion}

It has been previously demonstrated that pyrolysis at $230{ }^{\circ} \mathrm{C}$ of the fluorescent precursor CNP180 (derived via thermal treatment of EA and CA at $180{ }^{\circ} \mathrm{C}$ for $30 \mathrm{~min}$ as discussed in the experimental section) leads to the formation of well-defined spherical NPs (referred hereafter as CNP230) with average size of $19 \mathrm{~nm}$ [45]. In this study CNP180 was subjected to pyrolysis at $230{ }^{\circ} \mathrm{C}$, but in the presence of varying amounts of $\mathrm{Fe}(\mathrm{acac})_{3}$ and upon the addition of $\mathrm{PEG}_{400}$ in order to synthesize a series of well-defined C/Fe-NPs. Preliminary work indicated that both the PL intensity (Supplementary Materials, Figure S1) and the crystallinity (Supplementary Materials, Figure S2) of the C/Fe-NPs are optimized following $3 \mathrm{~h}$ of pyrolytic treatment, thus this pyrolysis time was kept constant for all experiments described here. TGA analysis suggests that $\mathrm{Fe}(\mathrm{acac})_{3}$ abruptly decomposes at temperatures around $230{ }^{\circ} \mathrm{C}$ (loss weight $91 \%$ at $236^{\circ} \mathrm{C}$ ), while $\mathrm{CNP} 180$ and $\mathrm{PEG}_{400}$ are much less prone to degradation in this temperature region (Figure $1 \mathrm{a}$ ).

The TGA profiles point to the early formation of iron-rich nuclei and the subsequent formation of carbon-rich corona (Scheme 2). Interestingly, C/17Fe-NPs continue being attracted by the magnet even after the completion of the TGA scan (up to $500{ }^{\circ} \mathrm{C}$ ) (Figure 1b). 


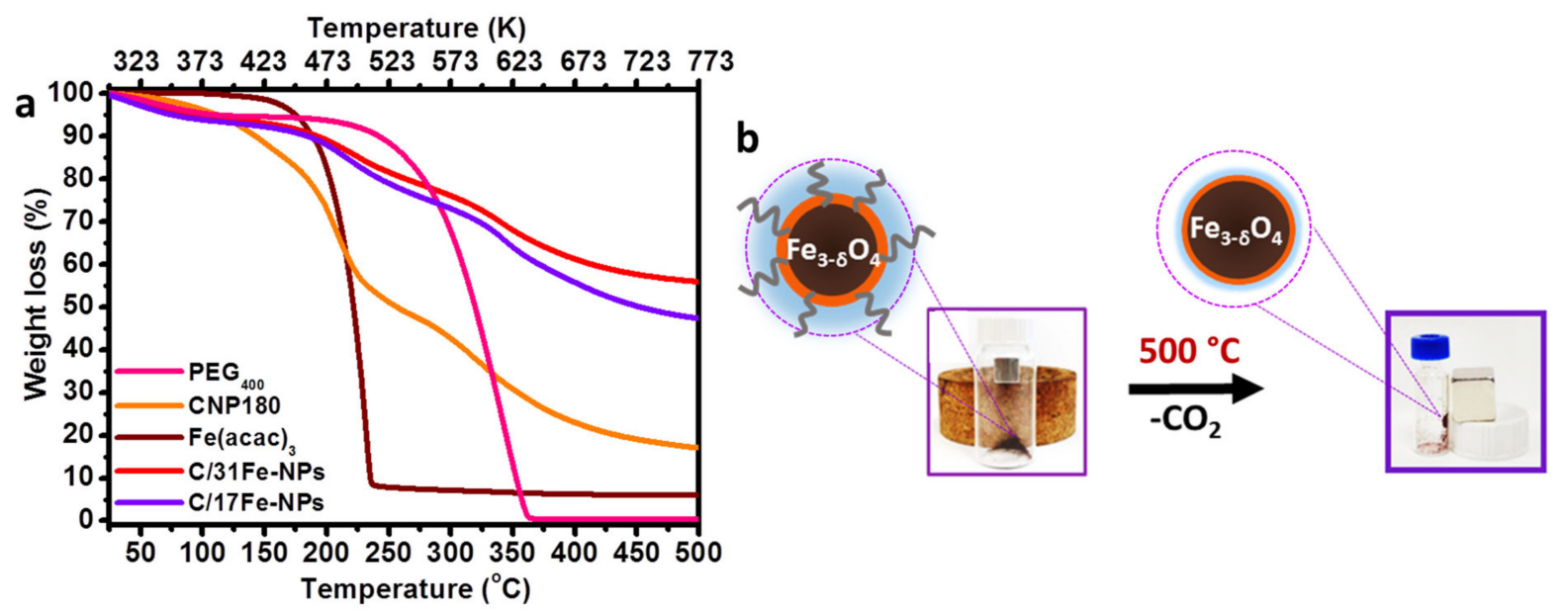

Figure 1. (a) TGA curves of $\mathrm{C} / 17 \mathrm{Fe}$ NPs, $\mathrm{C} / 31 \mathrm{Fe} \mathrm{NPs}, \mathrm{PEG}_{400}, \mathrm{CNP} 180$ and $\mathrm{Fe}(\mathrm{acac})_{3}$; (b) photos demonstrating the magnetic nature of $\mathrm{C} / 17 \mathrm{Fe}$ NPs prior (left image) and after (right image) the TGA scan presented in (a).

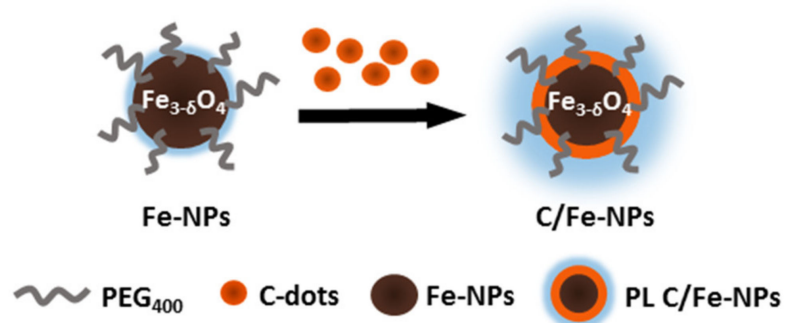

Scheme 2. Scheme presenting the build-up of C/Fe-NPs.

On the basis of this approach and by varying the weight ratio between $\mathrm{Fe}(\mathrm{acac})_{3}$ and CNP180, a series of C/Fe-NPs was synthesized. Elemental analysis (Table 1) suggested that the iron content of the $\mathrm{C} / \mathrm{Fe}-\mathrm{NPs}$ varies between 17 and $31 \mathrm{wt} \%$; hereafter the notation $\mathrm{C} / 17 \mathrm{Fe}-\mathrm{NPs}$ is used to indicate $17 \mathrm{wt} \%$ iron content, C/31Fe-NPs to indicate $31 \mathrm{wt} \%$ iron content, etc. At the same time, the carbon content monotonically decreases from 36.3 for C/17Fe-NPs to $26.9 \mathrm{wt} \%$ for C/31Fe-NPs. Within this family of materials, the oxygen, nitrogen and hydrogen contents are between 34.7 and $36.2 \mathrm{wt} \%, 3.9$ and $6.5 \mathrm{wt} \%$ and 3.6 and $4.3 \mathrm{wt} \%$, respectively.

Table 1. Elemental analysis of C/Fe-NPs.

\begin{tabular}{|c|c|c|c|c|c|}
\hline & $C(w t \%)$ & $H(w t \%)$ & $N(w t \%)$ & $\mathrm{O}(w t \%)$ & $\mathrm{Fe}(w t \%)$ \\
\hline CNP230 & 43.30 & 5.39 & 9.03 & 42.28 & - \\
\hline $\mathrm{C} / 17 \mathrm{Fe}-\mathrm{NPs}$ & 36.30 & 4.66 & 6.50 & 35.16 & 17.38 \\
\hline $\mathrm{C} / 23 \mathrm{Fe}-\mathrm{NPs}$ & 31.45 & 4.29 & 5.38 & 36.11 & 22.77 \\
\hline $\mathrm{C} / 24 \mathrm{Fe}-\mathrm{NPs}$ & 31.03 & 4.16 & 4.86 & 36.16 & 23.79 \\
\hline $\mathrm{C} / 27 \mathrm{Fe}-\mathrm{NPs}$ & 28.90 & 3.97 & 4.33 & 35.87 & 26.93 \\
\hline $\mathrm{C} / 31 \mathrm{Fe}-\mathrm{NPs}$ & 26.85 & 3.62 & 3.85 & 34.68 & 31.00 \\
\hline
\end{tabular}

A major advantage of our synthetic strategy is a facile one-pot and single-step fabrication procedure, which has potential to be easily scaled up and modified. In contrast, previous reports refer to tedious multistep synthetic procedures [16,29,36,38-44].

The TEM image of $\mathrm{C} / 17 \mathrm{Fe}-\mathrm{NPs}$ (Figure 2a) reveals the presence of nanoparticles with center-coating structure. In addition, C/17Fe-NPs demonstrate a relatively high level of homogeneity with an average particle size $6.4 \mathrm{~nm}$ (Figure $2 \mathrm{~b}$ ). The good separation between particles might be attributed to the presence of the carbogenic corona and the passivating role of $\mathrm{PEG}_{400}$ layer. 

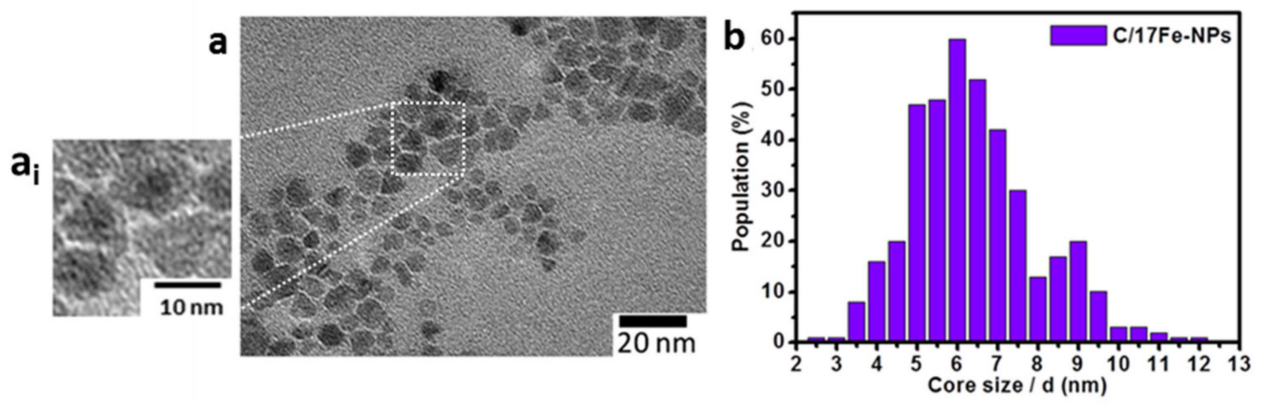

Figure 2. (a) TEM image with $\left(\mathrm{a}_{\mathrm{i}}\right)$ an inset demonstrating nucleus-corona structure and (b) size histogram of C/17Fe-NPs plotted on the basis of 395 fields.

The XPS survey spectrum of C/31Fe-NPs (Figure 3a) indicates a very low iron content on the surface, thus confirming that iron is predominantly located at the center. The highresolution $\mathrm{C} 1 \mathrm{~s}$ spectra of $\mathrm{C} / 31 \mathrm{Fe}-\mathrm{NPs}$ (Figure $3 \mathrm{~b}$ ) can be deconvoluted into three peaks located at $284.1 \mathrm{eV}, 285.7 \mathrm{eV}$ and $287.5 \mathrm{eV}$ that correspond to $\mathrm{C}-\mathrm{C} / \mathrm{C}=\mathrm{C}, \mathrm{C}-\mathrm{N} / \mathrm{C}=\mathrm{N}$ and $\mathrm{C}-$ $\mathrm{O} / \mathrm{C}=\mathrm{O}$, respectively $[34,38,49]$. The high-resolution Fe2p spectra of $\mathrm{C} / 31 \mathrm{Fe}-\mathrm{NPs}$ (Figure 3c) demonstrated the occurrence of $\mathrm{Fe} 2 \mathrm{p}_{3 / 2}$ and $\mathrm{Fe} 2 \mathrm{p}_{1 / 2}$ peaks centered around $722 \mathrm{eV}$ and 711 $\mathrm{eV}$, which point to $\mathrm{Fe}^{3+}$ and $\mathrm{Fe}^{2+}$ oxidation states of the air exposed $\mathrm{C} / \mathrm{Fe}-\mathrm{NPs}$ (assuming a certain level of porosity for the carbogenic corona), respectively $[35,38,49,50]$. The highresolution O1s spectra of C/31Fe-NPs (Figure 3d) can be deconvoluted into two peaks located around $531 \mathrm{eV}$ and $529 \mathrm{eV}$, which further confirm the presence of carboxyl groups and iron metal oxides, respectively. Similar results were obtained for other C/Fe-NPs.
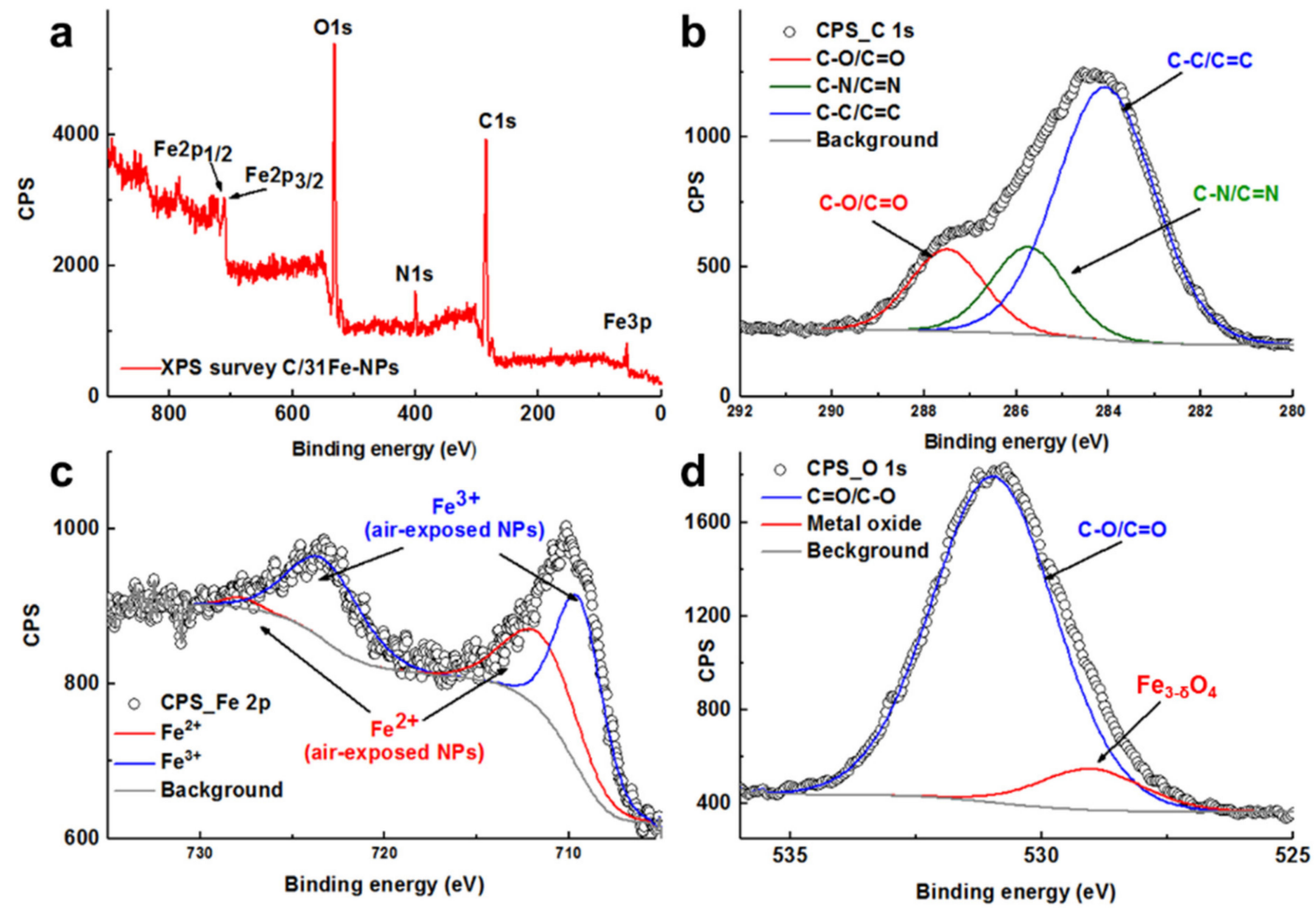

Figure 3. (a) The XPS survey together with deconvoluted (b) C1s, (c) Fe2p and (d) O1s XPS spectra of $\mathrm{C} / 31 \mathrm{Fe}-\mathrm{NPs}$. Circular points refer to the data collected, while the solid lines refer to the fitted curves. 
PXRD patterns for C/31Fe-NPs (Figure 4a), C/27Fe-NPs and C/24Fe-NPs (Supplementary Materials, Figure S3a) match well with the PDF card Nos. 19-0629 and 00-004-0755 of spinel-type (magnetite/maghemite) phase. The Bragg peaks appear much weaker for C/23Fe-NPs and C/17Fe-NPs (Supplementary Materials, Figure S3b), as expected due to their lower iron content. Profile refinements of the PXRD patterns (example in Figure 4a) indicated that the spinel-type phase is nanocrystalline, with the grain size decreasing slightly as the fraction of the iron oxides is reduced (Table 2).
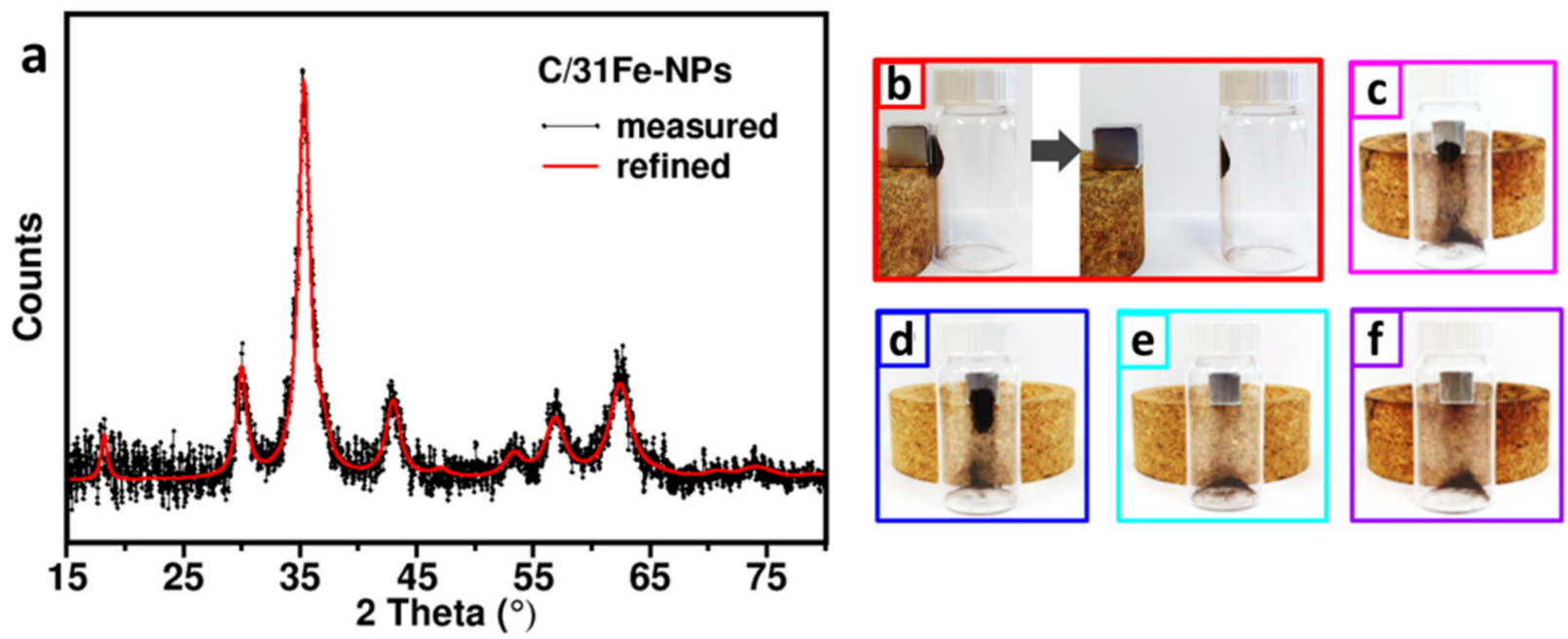

Figure 4. (a) PXRD pattern of $\mathrm{C} / 31 \mathrm{Fe}-\mathrm{NPs}$ (black points refer to experimental data and the red line refer to the refined profiles). The photos of (b) C/31Fe-NPs, (c) C/27Fe-NPs, (d) C/24Fe-NPs, (e) $\mathrm{C} / 23 \mathrm{Fe}-\mathrm{NPs}$, (f) $\mathrm{C} / 17 \mathrm{Fe}-\mathrm{NPs}$ (all enclosed in glass vials) in the presence of an external magnet.

Table 2. Volume weighted diameters of nanoparticle cores $D_{V}$ estimated from powder X-ray diffraction patterns as detailed in the Materials and Methods Section.

\begin{tabular}{cc}
\hline Sample & D $_{\mathbf{V}}(\mathbf{n m})$ \\
\hline C/31Fe-NPs & $4.6 \pm 0.6$ \\
C/27Fe-NPs & $4.0 \pm 0.7$ \\
C/24Fe-NPs & $3.5 \pm 0.8$ \\
C/23Fe-NPs & $3.0 \pm 0.8$ \\
C/17Fe-NPs & $2.7 \pm 0.9$ \\
\hline
\end{tabular}

As shown in Figure $4 \mathrm{~b}-\mathrm{f}$, only C/31Fe-NPs, C/27Fe-NPs and C/24Fe-NPs are strongly attracted by a magnet, while $\mathrm{C} / 23 \mathrm{Fe}-\mathrm{NPs}$ and $\mathrm{C} / 17 \mathrm{Fe}-\mathrm{NPs}$ fail to do so.

The FTIR spectra of $\mathrm{C} / \mathrm{Fe}-\mathrm{NPs}$ (Figure 5) show the presence of peaks centered around $588 \mathrm{~cm}^{-1}$ (Fe-O stretching vibration), $1054 \mathrm{~cm}^{-1}$ (C-OH stretching vibration), $1232-1352 \mathrm{~cm}^{-1}$ (C-O and C-N stretching vibrations), $1750 \mathrm{~cm}^{-1}$ (C=O stretching vibration), $2900 \mathrm{~cm}^{-1}$ (C-H symmetric and asymmetric stretching vibrations) and $3240 \mathrm{~cm}^{-1}(\mathrm{~N}-\mathrm{H}$ and $\mathrm{O}-\mathrm{H}$ stretching vibrations) $[16,34,38,39,49,51]$. The peaks in the range of $1540-1697 \mathrm{~cm}^{-1}$ are associated with the $\mathrm{C}=\mathrm{O}$ stretching and $\mathrm{N}-\mathrm{H}$ in-plane bending vibrations of amide I and II absorption band, respectively $[35,39,40,49,52]$. The FTIR spectroscopy confirms the presence of oxygen-rich groups on the $\mathrm{C} / \mathrm{Fe}-\mathrm{NPs}$ surface that render the particles dispersible in polar media.

Figure 6 shows typical ZFC and FC curves recorded from selected C/Fe-NP samples in magnetic field of 100 Oe. The magnetic susceptibilities obtained in the ZFC mode show broad peaks signifying a transition from the low temperature blocked state to the superparamagnetic regime at high temperatures [53]. The blocking temperatures $\left(T_{B}\right)$ corresponding to the maxima in the ZFC curves are higher for samples with larger Fe 
content, in agreement with the conjecture that those samples contain bigger Fe-NPs which are expected to become superparamagnetic at higher temperatures [54].

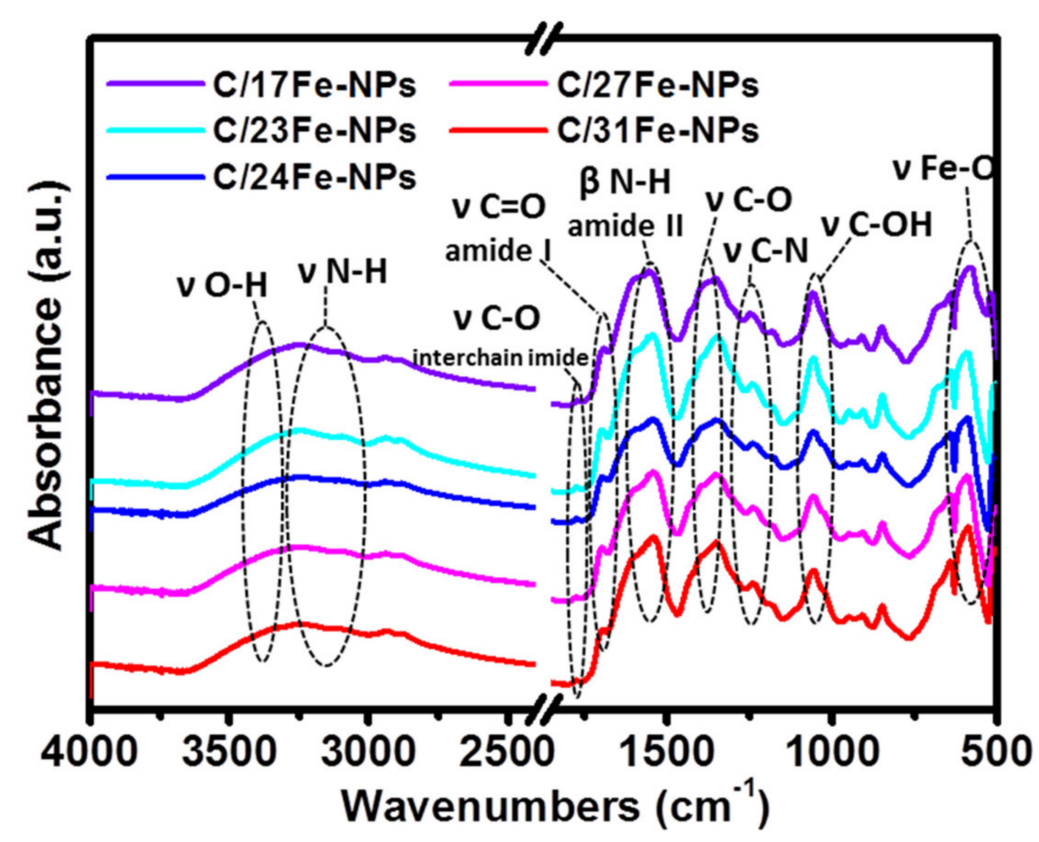

Figure 5. The FTIR spectra of C/Fe-NPs.

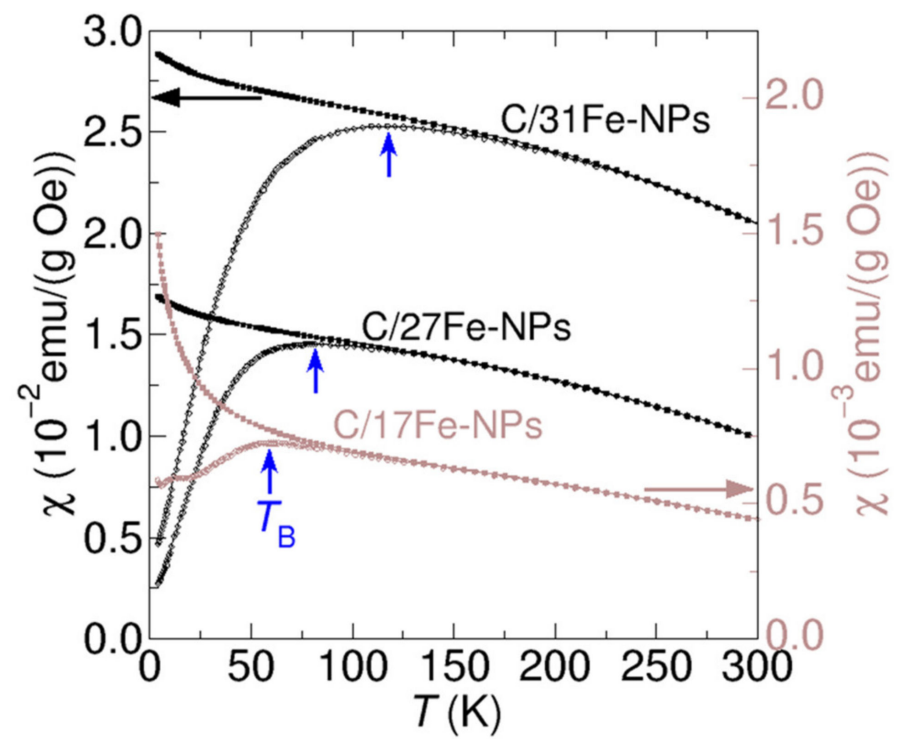

Figure 6. Temperature dependencies of magnetic susceptibilities for selected C/Fe-NPs measured in the ZFC (empty dots) and FC (filled dots) modes using the applied magnetic field of 100 Oe. Data shown in black was plotted on the left vertical axis, whereas brown data points are using the brown vertical axis located on the right-hand side. The blocking temperatures are indicated by vertical blue arrows.

The isothermal magnetization measurements shown in Figure 7 further indicate that $\mathrm{C} / \mathrm{Fe}-\mathrm{NPs}$ exhibit a predominant superparamagnetic behavior close to room temperature. Upon cooling, onset of hysteresis loops are observed in the $M(H)$ curves at temperatures between 150 and $50 \mathrm{~K}$ indicating transitions to the blocked state. As shown in insets i of Figure 7, the coercivity increases with decreasing temperature, reaching values of $0.25-0.30 \mathrm{kOe}$ at $4 \mathrm{~K}$. 

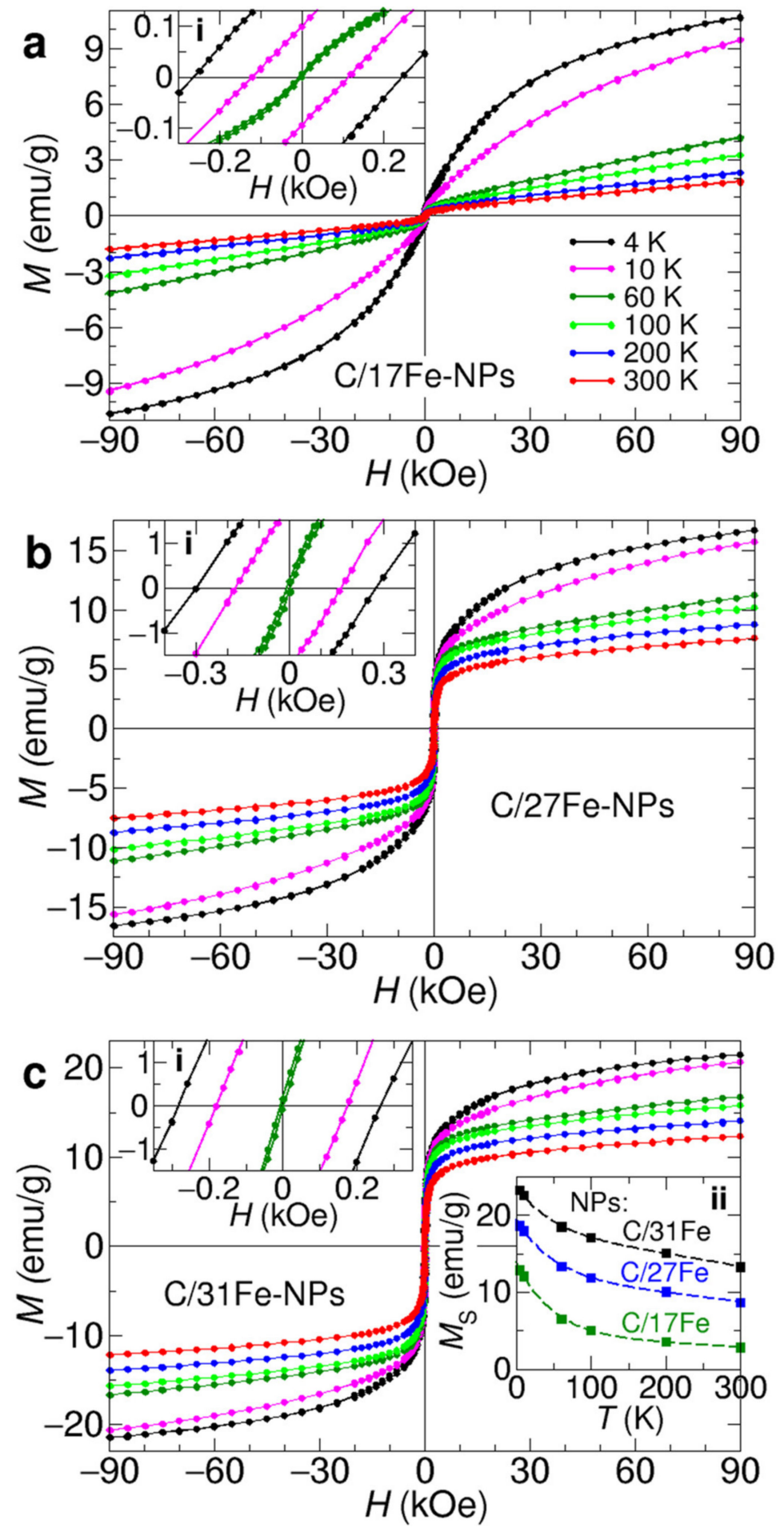

Figure 7. Magnetic hysteresis loops recorded at temperatures of $4 \mathrm{~K}$ (black dots), $10 \mathrm{~K}$ (pink dots), $60 \mathrm{~K}$ (dark greed dots), $100 \mathrm{~K}$ (green dots), $200 \mathrm{~K}$ (blue dots) and $300 \mathrm{~K}$ (red dots) from C/17Fe-NPs (a), C/27Fe-NPs (b) and C/31Fe-NPs (c). Insets i show expanded $M-H$ plots near the origin. Inset ii of (c) presents the saturation magnetization as a function of temperature for C/17Fe-NPs (black squares), C/27Fe-NPs (blue squares) and C/31Fe-NPs (dark green squares), together with fits using Equation (5) (dashed lines).

The magnetization of $\mathrm{C} / \mathrm{Fe}-\mathrm{NPs}$ does not reach saturation even at $90 \mathrm{kOe}$ and $4 \mathrm{~K}$. Therefore, the saturation magnetization $\left(M_{\mathrm{S}}\right)$ was estimated by extrapolating the magnetization versus $1 / H$ to the limit when the inverse magnetic field approaches zero. The resulting 
$M_{\mathrm{S}}$ values for selected C/Fe-NPs are shown in inset ii of Figure 7c. When calculated per gram of $\mathrm{Fe}_{3-\delta} \mathrm{O}_{4}(0 \leq \delta \leq 0.33)$, the $M_{\mathrm{s}}$ values at $4 \mathrm{~K}$ fall within $50-56 \mathrm{emu} / \mathrm{g}-\mathrm{Fe}_{3-\delta} \mathrm{O}_{4}$ and are smaller than 90 and $84 \mathrm{emu} / \mathrm{g}$ expected for bulk magnetite and maghemite, respectively [55]. We note that substantially reduced $M_{\mathrm{s}}$ is characteristic for Fe-NPs with sizes in the surface of spinel cores [53,56-63]. The saturation magnetization of C/Fe-NPs decreases the range of a few nanometers and was attributed to the presence of disordered spins on upon heating, signifying thawing of the surface spins [64-66].

As illustrated in inset ii of Figure 7c, the temperature dependencies of Ms can be well described by the phenomenological formula $[66,67]$.

$$
M_{\mathrm{S}}(T) / M_{\mathrm{S}}(0)=\left(1-B T^{3 / 2}\right)+A \exp \left(-T / T_{\mathrm{f}}\right)
$$

in which the first term accounts for a Bloch-like variation of magnetization expected for magnetically ordered core moments whereas the second term represents the effect of freezing of disordered surface spins in a spin-glass-like state at temperatures below $T_{\mathrm{f}}$. Fitting Equation (5) to the $M s(T)$ data resulted in parameters collated in Table 3. The obtained values of the Bloch constant $B$ are similar to those previously reported $[67,68]$ for NPs of $\mathrm{Fe}_{3} \mathrm{O}_{4}$ and $\gamma-\mathrm{Fe}_{2} \mathrm{O}_{3}$ with comparable sizes. The $A$ constant scales with the relative amount of surface spins compared to magnetically ordered core moments. Therefore, the observed systematic increase in the $A$ values as the Fe content is reduced indicates a growing fraction of surface spins, in line with an increasing surface-to-volume ratio expected when spinel NPs are getting smaller. Simultaneously, the saturation magnetization ascribed to the magnetically ordered spinel cores dwindles, providing a further indication for a decrease in sizes of Fe-centers as the Fe content is reduced.

Table 3. Magnetic parameters derived from least-squares fits of the $M_{\mathrm{S}}(T)$ data shown in the inset ii of Figure 7c with Equation (5).

\begin{tabular}{|c|c|c|c|c|}
\hline Sample & $A(-)$ & B $\left(10^{-5} \mathrm{~K}^{-3 / 2}\right)$ & $\mathrm{T}_{\mathrm{f}}(\mathrm{K})$ & $M_{s}(0)(e m u / g)$ \\
\hline C/31Fe-NPs & $0.42 \pm 0.05$ & $4.0 \pm 0.2$ & $52 \pm 2$ & $17.7 \pm 0.5$ \\
\hline C/27Fe-NPs & $0.75 \pm 0.08$ & $4.2 \pm 0.2$ & $53 \pm 2$ & $11.7 \pm 0.4$ \\
\hline C/17Fe-NPs & $2.57 \pm 0.15$ & $5.2 \pm 0.3$ & $49 \pm 2$ & $4.1 \pm 0.1$ \\
\hline
\end{tabular}

The UV-Vis spectra of magnetic C-dots (Supplementary Materials, Figure S4a) reveals the presence of absorption peaks at $270 \mathrm{~nm}$ and a hump around $320 \mathrm{~nm}$, which are attributed to $\pi-\pi^{*}$ electron transitions of polyaromatic chromophores as well as n- $\pi^{*}$ electron transitions of carbonyl $(\mathrm{C}=\mathrm{O})$ and amine $(\mathrm{C}-\mathrm{N})$ functional groups $[33,35,39,44]$. Although the absorptivity of aqueous dispersions of $\mathrm{C} / \mathrm{Fe}-\mathrm{NPs}$ are rather low $[39,49,69,70]$, their aqueous dispersions display a strong blue luminescence under UV light (Supplementary Materials, Figure S4b). The fluorescence spectra of C/31Fe-NPs and C/17Fe-NPs (Figure 8) show an excitation wavelength independent contribution $\left(\lambda_{\mathrm{em}}=455 \mathrm{~nm}\right)$ that has been attributed to the presence of citrazinic acid and an excitation wavelength dependent emission at higher $\lambda_{\text {ex }}$ that is characteristic for carbogenic NPs [45]. This fluorescent mode arises from surface emission states, edge defects, self-trapped excitons, crosslink enhanced emission and quantum conferment in the context of $\mathrm{sp}^{2}$ islands within $\mathrm{ab} \mathrm{sp} \mathrm{sp}^{3}$ matrix $[16,34,35,39,50]$. Typically C-dots exhibit the strongest PL within the blue region [71], but red-shifted emission is achieved via $\pi$-conjugation of nano-domains, pronounced surface oxidation and incorporation of heteroatoms, such as N, S and P [72].

As shown in Supplementary Materials, Figure S5, the QY at $\lambda_{\mathrm{ex}}=365 \mathrm{~nm}$ increases with carbon content from $6 \%$ for $\mathrm{C} / 31 \mathrm{Fe}-\mathrm{NPs}, \mathrm{C} / 27 \mathrm{Fe}-\mathrm{NPs}$ and $\mathrm{C} / 24 \mathrm{Fe}-\mathrm{NPs}$ to $7 \%$ for $\mathrm{C} / 23 \mathrm{Fe}-\mathrm{NPs}$ and $9 \%$ for $\mathrm{C} / 17 \mathrm{Fe}-\mathrm{NPs}$. These values are consistent with previous studies that reported QY ranging from 4.6 to $8 \%$ for related systems $[33,49,50]$. The time-resolved PL lifetime decays at $\lambda_{\mathrm{ex}}=375 \mathrm{~nm}$ (Supplementary Materials, Figure S6) and $450 \mathrm{~nm}$ (Supplementary Materials, Figure S7) of aqueous dispersions of C/Fe-NPs follow complex multi-exponential decay profiles, in agreement with previous studies [39]. The average PL 
lifetimes $\left(\tau_{\mathrm{avg}}\right.$ ) of C/Fe-NPs range from 12.43 up to $12.80 \mathrm{~ns}$ (Supplementary Materials, Figure S6) compared to $\tau_{\mathrm{avg}}=13.06 \mathrm{~ns}$ for CNP230 (Supplementary Materials, Figure S8), $\tau_{\mathrm{avg}}=1.5-4 \mathrm{~ns}$ for the auto fluorescence of the cells, $\tau_{\mathrm{avg}}=1-5 \mathrm{~ns}$ for organic dyes and $\tau_{\mathrm{avg}}=6.4 \mathrm{~ns}$ for citrazinic acid. These data indicate a weak dependence on the iron content and a rather limited effect of the magnetic core on the microenvironment of the excited states within the carbogenic corona. The larger $\tau_{\text {avg }}$ observed for C/Fe-NPs carry promise for cellular labelling, tissue analysis and microfluidic devices [73].
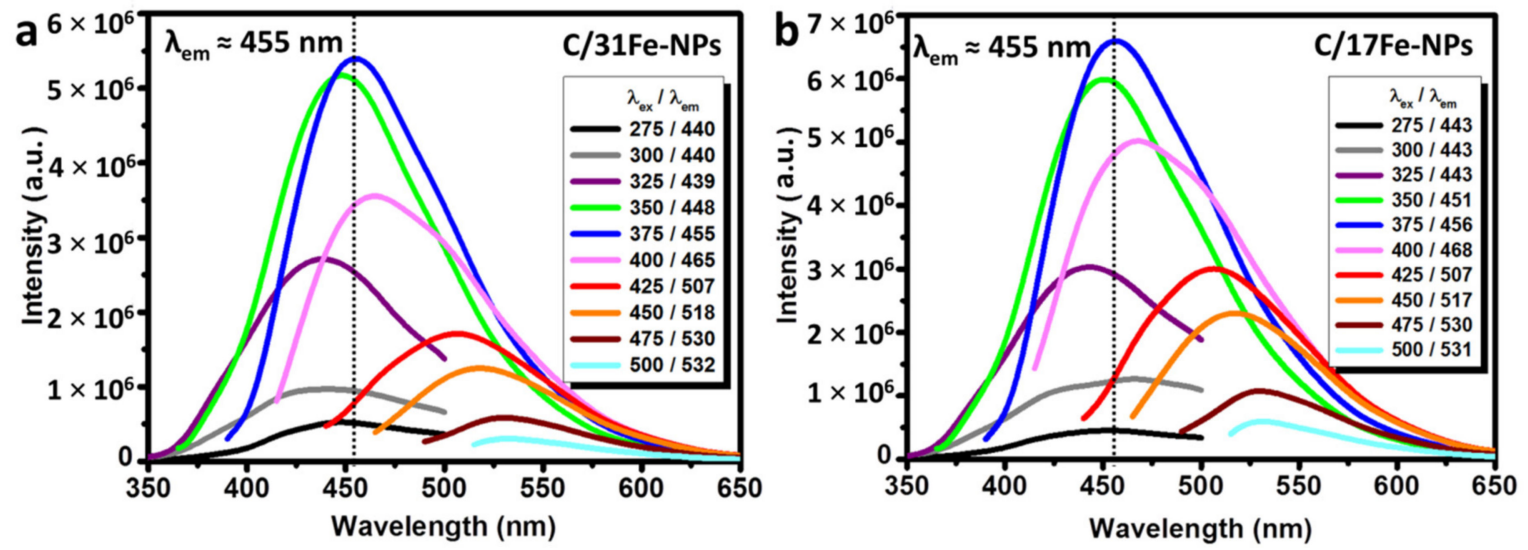

Figure 8. PL spectra of aqueous dispersions of (a) C/31Fe-NPs and (b) C/17Fe-NPs.

The viability of HeLa cancer cells incubated with various concentrations of $\mathrm{C} / \mathrm{Fe}-$ NPs (as estimated using standard MTT assays) is shown in Figure 9. At the highest concentration studied $(200 \mu \mathrm{g} / \mathrm{mL})$, the viability of HeLa cells was found to be $95 \%$ for C/17Fe-NPs, $91 \%$ for C/23Fe-NPs, $90 \%$ for C/24Fe-NPs, $87 \%$ for C/28Fe-NPs and $86 \%$ for $\mathrm{C} / 31 \mathrm{Fe}-\mathrm{NPs}$. For comparison, the viability of Hela cells incubated with $200 \mu \mathrm{g} / \mathrm{mL}$ of CNP230 (Supplementary Materials, Figure S9) and Fe-NPs is 97 and 61\%, respectively. In principle, the cytotoxicity of NPs critically depends upon the nature of the surface functional groups [74]. Previous studies demonstrated the low toxicity of C-dots derived from CA and EA [39], in contrast to the toxic nature of heavy-metal based quantum [75] and the cell type-specific activity of the Fe-NPs [76,77].

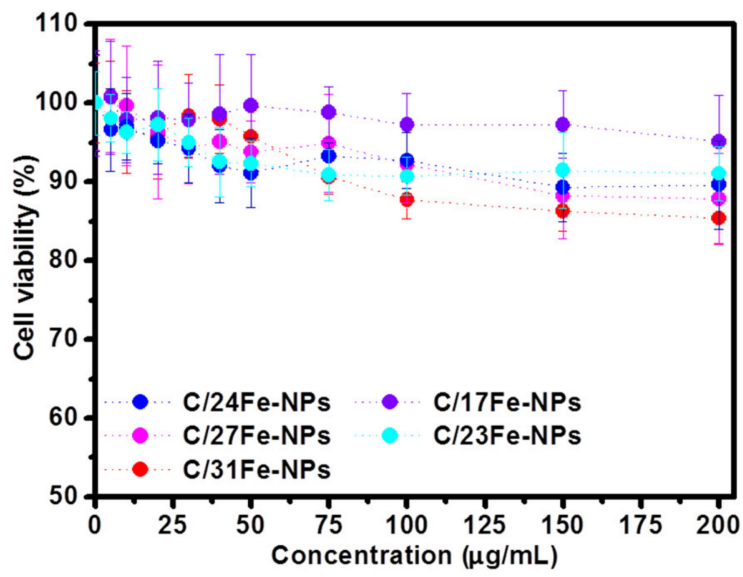

Figure 9. The viability of HeLa cells derived from MTT assay following $24 \mathrm{~h}$ incubation with $\mathrm{C} / \mathrm{Fe}-\mathrm{NPs}$.

Fluorescent microscope images of HeLa cells following incubation with $\mathrm{C} / 31 \mathrm{Fe}-\mathrm{NPs}$ (Figure 10a) and C/17Fe-NPs (Figure 10b) for $24 \mathrm{~h}$ indicated that C/Fe-NPs penetrate the cells and are predominantly accumulated in the cytoplasm [40]. When illuminated 
with blue, green and red radiation, the internalized C/Fe-NPs can reveal morphological information regarding both the cytoplasm and the membranes.

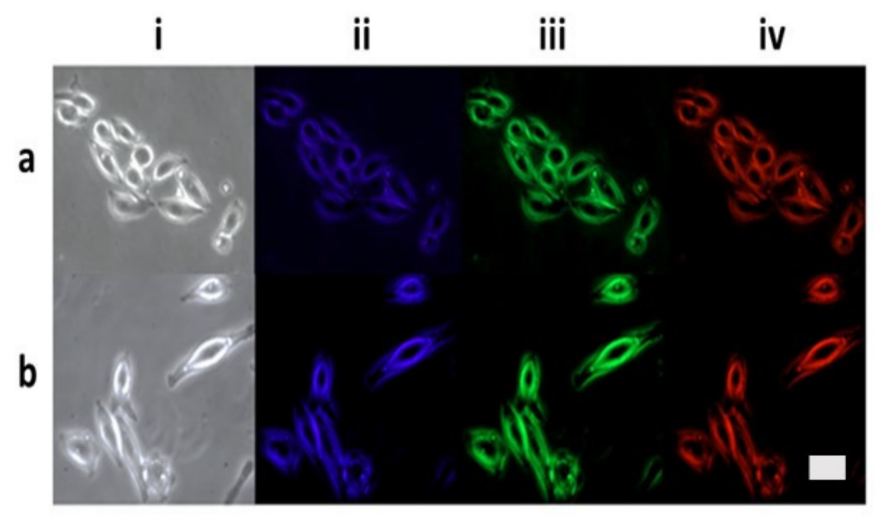

Figure 10. Fluorescent microscope images of HeLa cells following incubation with: (a) C/31Fe-NPs and (b) C/17Fe-NPs under the bright field (i) as well as the UV (ii), blue (iii) and green (iv) excitation wavelengths. The scale bar corresponds to $100 \mu \mathrm{m}$.

Overall C/Fe-NPs with low cytotoxicity and superior fluorescent properties act as efficient surveillance probes, while having the added advantage of being able to be directed via an external magnetic field to targeted destinations [35].

Finally, the antimicrobial activities of CNP230 and C/Fe-NPs were tested against S. aureus and E. coli (a representative Gram-positive and Gram-negative strain, respectively). As summarized in Table 4, C/Fe-NPs demonstrate excellent antimicrobial activity after incubation with bacterial species for $24 \mathrm{~h}$ at $37{ }^{\circ} \mathrm{C}$, causing 99.0-99.9\% and 99.5-99.9\% reduction in E. coli and S. aureus colonies, respectively. Very similar performance was observed for CNP230 as well as for a variety of C-dots-based materials [78], while Fe-NPs synthesized as a control sample via the same synthetic approach but without the carbogenic coating displayed $91.4 \%$ and $99.9 \%$ decrease in E. coli and S. aureus under identical conditions, respectively $[37,79]$. The photo-activated antimicrobial mechanism of C-dots has been largely associated with the formation of reactive oxygen species (ROS), while the occurrence of nanoparticle-bacterial membrane electrostatic attractions can damage the membrane leading to leakage of the cytoplasm [80]. The data suggest that C/Fe-NPs could be viewed as highly reliable antimicrobial agents, able to combat bacterial contamination, preventing infectious diseases [81]. We note that a magnet can be employed to direct (and eventually withdraw) the C/Fe-NPs in otherwise inaccessible locations, affording disinfection and bacterial decontamination in a controlled manner.

Table 4. Antimicrobial performance of CNP230 and C/Fe-NPs.

\begin{tabular}{ccc}
\hline & Escherichia coli & Staphylococcus aureus \\
\cline { 2 - 3 } Material & \% decrease & \% decrease \\
& $\mathbf{2 4} \mathbf{~ h}$ & $\mathbf{2 4} \mathbf{h}$ \\
CNP230 & 99.9 & 99.9 \\
C/17Fe-NPs & 99.9 & 99.9 \\
C/23Fe-NPs & 99.9 & 99.9 \\
C/24Fe-NPs & 99.9 & 99.9 \\
C/27Fe-NPs & 99.0 & 99.5 \\
C/31Fe-NPs & 99.5 & 99.9 \\
\hline
\end{tabular}

\section{Conclusions}

The study presents a facile strategy to fine-tune the structure and the chemical composition and, thereby, the optical and magnetic properties of C/Fe-NPs. A systematic investigation within this series of materials indicated that the $C / 17 \mathrm{Fe}-\mathrm{NPs}$ with carbon 
content $36 \mathrm{wt} \%$ and iron content $17 \mathrm{wt} \%$ show QY close to $9 \%$ and magnetization $4.1 \mathrm{emu} / \mathrm{g}$, while C/31Fe-NPs with carbon content $27 \mathrm{wt} \%$ and iron content $31 \mathrm{wt} \%$ show QY $6 \%$ and magnetization $17.7 \mathrm{emu} / \mathrm{g}$ (Figure 11). C/Fe-NPs are non-toxic materials that can be used as advanced diagnostic tools, while showing excellent antimicrobial activity against E. coli and $S$. aureus.

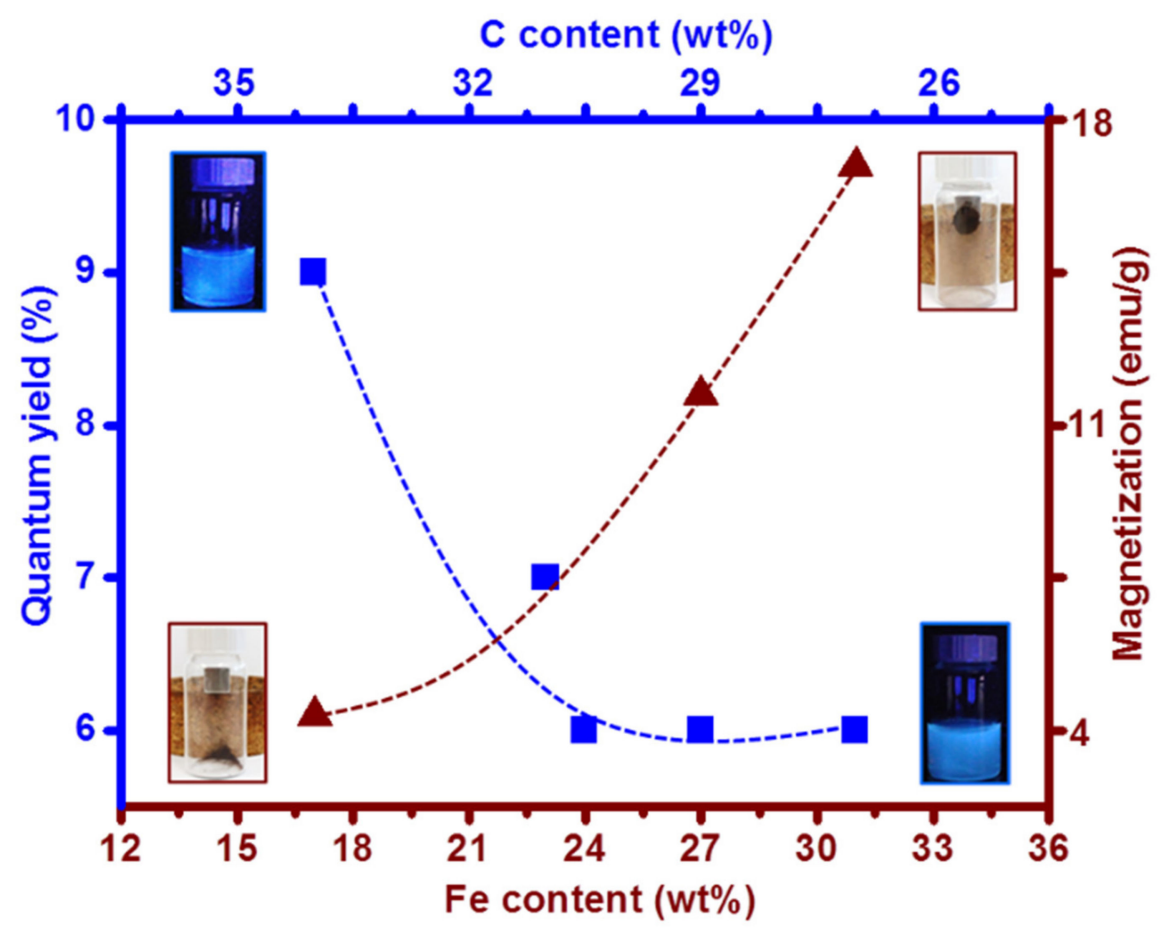

Figure 11. Quantum yield and magnetization of a series of C/Fe-NPs with varying $C$ and Fe contents. Blue squares correspond to $\mathrm{QY}$ as a function of $\mathrm{C}$ content and brown triangles correspond to magnetization as a function of Fe content.

Supplementary Materials: The following are available online at https:/ /www.mdpi.com/article/10 $.3390 /$ nano12040674/s1, Figure S1. (a) The PL spectra $\left(\lambda_{\mathrm{ex}}=375 \mathrm{~nm}\right)$ of aqueous dispersions of C/FeNPs prepared from identical reactant mixtures with $\mathrm{C} / 31 \mathrm{Fe}-\mathrm{NPs}$, but at various times of pyrolysis (b); Figure S2. PXRD patterns of $\mathrm{C} / \mathrm{Fe}-\mathrm{NPs}$ prepared from identical reactant mixtures with $\mathrm{C} / 31 \mathrm{Fe}-\mathrm{NPs}$ but at various times of pyrolysis; Figure S3. (a) PXRD patterns of C/27Fe-NPs (magenta) and C/24FeNPs (blue) along with (b) PXRD patterns of C/23Fe-NPs (cyan) and C/17Fe-NPs (violet); Figure S4. (a) Absorption spectra of aqueous dispersions of $0.01 \mathrm{mg} / \mathrm{mL} \mathrm{C} / \mathrm{Fe}-\mathrm{NPs}$; (b) Photos of C/31Fe-NPs (red), C/24Fe-NPs (blue) and C/17Fe-NPs (purple) under daylight and ultraviolet light; Figure S5. Integrated PL intensity of (a) C/17Fe-NPs, (b) C/23Fe-NPs, (c) C/24Fe-NPs, (d) C/27Fe-NPs and (e) $\mathrm{C} / 31 \mathrm{Fe}-\mathrm{NPs}$ in water as a function of optical absorbance at $365 \mathrm{~nm}$; Figure S6. Time-resolved fluorescence decay profiles for aqueous solutions of (a) C/17Fe-NPs, (b) C/23Fe-NPs, (c) C/24Fe-NPs, (d) C/27Fe-NPs, (e) C/31Fe-NPs (e) at $\lambda_{\text {ex }}=375 \mathrm{~nm}$; Figure S7. Time-resolved fluorescence decay profiles for aqueous solutions of (a) C/17Fe-NPs, (b) C/23Fe-NPs, (c) C/24Fe-NPs, (d) C/27Fe-NPs, (e) $\mathrm{C} / 31 \mathrm{Fe}-\mathrm{NPs}$ at $\lambda_{\mathrm{ex}}=450 \mathrm{~nm}$; Figure S8. Time-resolved fluorescence decay profiles for aqueous solutions of CNP230 recorded at $\lambda_{\mathrm{ex}}=375 \mathrm{~nm}$ (grey colour) and $\lambda_{\mathrm{ex}}=450 \mathrm{~nm}$ (dark yellow colour); Figure S9. (a) The MTT assay results for HeLa cells incubated with CNP230 for $24 \mathrm{~h}$; (b) The fluorescence microscope images of HeLa cells with internalized CNP230.

Author Contributions: Conceptualization, A.K. and J.D.S.; methodology, J.D.S., M.B.G., E.N.G. and C.M.; resources, A.S.; data curation, J.D.S., M.B.G., E.N.G., E.G.-C. and A.S.; writing-original draft preparation, J.D.S. and A.K.; writing-review and editing, J.D.S. and A.K.; supervision, A.K., M.B.G., C.M., M.J.K., T.S. and C.K.; project administration, A.K. All authors have read and agreed to the published version of the manuscript. 
Funding: Financial support from the Higher Education Innovation Fund (Research England) and UCLan Research Centre for Smart Materials is gratefully acknowledged.

Data Availability Statement: The data presented in this study are available on request from the corresponding author.

Conflicts of Interest: The authors declare no conflict of interest.

\section{References}

1. Demirer, G.S.; Okur, A.C.; Kizilel, S. Synthesis and Design of Biologically Inspired Biocompatible Iron Oxide Nanoparticles for Biomedical Applications. J. Mater. Chem. B 2015, 3, 7831-7849. [CrossRef] [PubMed]

2. Shen, L.; Li, B.; Qiao, Y. $\mathrm{Fe}_{3} \mathrm{O}_{4}$ Nanoparticles in Targeted Drug/Gene Delivery Systems. Materials 2018, 11, 324. [CrossRef] [PubMed]

3. Xie, L.; Jin, W.; Zuo, X.; Ji, S.; Nan, W.; Chen, H.; Gao, S.; Zhang, Q. Construction of small-sized superparamagnetic Janus nanoparticles and their application in cancer combined chemotherapy and magnetic hyperthermia. Biomater. Sci. 2020, 8 , 1431-1441. [CrossRef] [PubMed]

4. Lu, A.H.; Salabas, E.L.; Schuth, F. Magnetic Nanoparticles: Synthesis, Protection, Functionalization, and Application. Angew. Chem. Int. Ed. 2007, 46, 1222-1244. [CrossRef]

5. Lee, N.; Yoo, D.; Ling, D.; Cho, M.H.; Hyeon, T.; Cheon, J. Iron Oxide Based Nanoparticles for Multimodal Imaging and Magnetoresponsive Therapy. Chem. Rev. 2015, 115, 10637-10689. [CrossRef]

6. Fedorenko, S.; Stepanov, A.; Zairov, R.; Kaman, O.; Amirov, R.; Nizameev, I.; Kholin, L.; Ismaev, I.; Voloshina, A.; Sapunova, A.; et al. One-pot embedding of iron oxides and Gd(III) complexes into silica nanoparticles-Morphology and aggregation effects on MRI dual contrasting ability. Colloids Surf. A Physicochem. Eng. 2018, 559, 60-67. [CrossRef]

7. Wu, W.; Jiang, C.Z.; Roy, V.A.L. Designed synthesis and surface engineering strategies of magnetic iron oxide nanoparticles for biomedical applications. Nanoscale 2016, 8, 19421-19474. [CrossRef]

8. Xu, C.; Sun, S. Applications of Iron Oxide-Based Magnetic Nanoparticles in the Diagnosis and Treatment of Bacterial Infections. Front. Bioeng. Biotechnol. 2019, 7, 141. [CrossRef]

9. Sun, S.; Zeng, H. Size-Controlled Synthesis of Magnetite Nanoparticles. J. Am. Chem. Soc. 2002, 124, 8204-8205. [CrossRef]

10. Majumdar, B.; Sarma, D.; Jain, S.; Sarma, T.K. One-Pot Magnetic Iron Oxide-Carbon Nanodot Composite-Catalyzed Cyclooxidative Aqueous Tandem Synthesis of Quinazolinones in the Presence of tert-Butyl Hydroperoxide. ACS Omega 2018, 3, 13711-13719. [CrossRef]

11. Chung, S.; Zhang, M. Microwave-Assisted Synthesis of Carbon Dot-Iron Oxide Nanoparticles for Fluorescence Imaging and Therapy. Front. Bioeng. Biotechnol. 2021, 9, 9. [CrossRef] [PubMed]

12. Itoh, H.; Sugimoto, T. Systematic control of size, shape, structure, and magnetic properties of uniform magnetite and maghemite particles. J. Colloid Interface Sci. 2003, 265, 283-295. [CrossRef]

13. Effenberger, F.B.; Couto, R.A.; Kiyohara, P.K.; Machado, G.; Masunaga, S.H.; Jardim, R.F.; Rossi, L.M. Economically attractive route for the preparation of high quality magnetic nanoparticles by the thermal decomposition of iron(III) acetylacetonate. Nanotechnology 2017, 28, 115603-115611. [CrossRef] [PubMed]

14. Shen, W.Z.; Cetinel, S.; Sharma, K.; Borujeny, E.R.; Montemagno, C. Peptide-functionalized iron oxide magnetic nanoparticle for gold mining. J. Nanoparticle Res. 2017, 19, 74. [CrossRef]

15. Kumar, A.; Jena, P.K.; Behera, S.; Lockey, R.F.; Mohapatra, S. Multifunctional magnetic nanoparticles for targeted delivery. Nanomed. Nanotechnol. Biol. Med. 2010, 6, 64-69. [CrossRef]

16. Jin, H.; Gui, R.; Sun, J.; Wang, Y. Facilely self-assembled magnetic nanoparticles/aptamer/carbon dots nanocomposites for highly sensitive up-conversion fluorescence turn-on detection of tetrodotoxin. Talanta 2018, 176, 277-283. [CrossRef]

17. Liang, J.; Zhang, X.; Miao, Y.; Li, J.; Gan, Y. Lipid-coated iron oxide nanoparticles for dual-modal imaging of hepatocellular carcinoma. Int. J. Nanomed. 2017, 12, 2033-2044. [CrossRef]

18. Akbarzadeh, A.; Mikaeli, H.; Zanghami, N.; Mohammad, R.; Barkhordari, A.; Davaran, S. Preparation and in vitro evaluation of doxorubicin loaded $\mathrm{Fe}_{3} \mathrm{O}_{4}$ magnetic nanoparticles modified with biocompatible copolymers. Int. J. Nanomed. 2012, 7, 511-526.

19. Cai, L.; Dai, Y.; Cao, A.; Cao, M. The effects of $\mathrm{CS} @ \mathrm{Fe}_{3} \mathrm{O}_{4}$ nanoparticles combined with microwave or far infrared thawing on microbial diversity of red seabream (Pagrus major) fillets based on high-throughput sequencing. Food Microbiol. 2020, 91, 103511-103518. [CrossRef]

20. Cai, H.; Li, K.; Li, J.; Wen, S.; Chen, Q.; Shen, M.; Zheng, L.; Zhang, G.; Shi, X. Dendrimer-Assisted Formation of Fe $\mathrm{O}_{4} / \mathrm{Au}$ Nanocomposite Particles for Targeted Dual Mode CT/MR Imaging of Tumors. Small 2015, 11, 4584-4593. [CrossRef]

21. Lastovina, T.A.; Bugaev, A.L.; Kubrin, S.P.; Kudryavstev, E.A.; Soldatov, A.V. Structural studies of magnetic nanoparticles doped with rare-earth elements. J. Struct. Chem. 2016, 57, 1444-1449. [CrossRef]

22. Wu, Y.; Ma, Y.; Xu, G.; Wei, F.; Ma, Y.; Song, Q.; Wang, X. Metal-organic framework coated $\mathrm{Fe}_{3} \mathrm{O}_{4}$ magnetic nanoparticles with peroxidase-like activity for colorimetric sensing of cholesterol. Sens. Actuators B Chem. 2017, 249, 195-202. [CrossRef]

23. He, F.; Fan, J.; Ma, D.; Zhang, L.; Leung, C.; Chan, H.L. The attachment of $\mathrm{Fe}_{3} \mathrm{O}_{4}$ nanoparticles to graphene oxide by covalent bonding. Carbon 2010, 48, 3139-3144. [CrossRef] 
24. Zhao, T.; Ji, X.; Guo, X.; Jin, W.; Dang, A.; Li, H.; Li, T. Preparation and electrochemical property of $\mathrm{Fe}_{3} \mathrm{O}_{4} / \mathrm{MWCNT}$ nanocomposite. Chem. Phys. Lett. 2016, 653, 202-206. [CrossRef]

25. Sepahvand, S.; Farhadi, S. Fullerene-modified magnetic silver phosphate $\left(\mathrm{Ag}_{3} \mathrm{PO}_{4} / \mathrm{Fe}_{3} \mathrm{O}_{4} / \mathrm{C}_{60}\right)$ nanocomposites: Hydrothermal synthesis, characterization and study of photocatalytic, catalytic and antibacterial activities. RSC Adv. 2018, 8, 10124-10140. [CrossRef]

26. Chekina, N.; Horak, D.; Jendelova, P.; Trchova, M.; Benes, M.J.; Hruby, M.; Herynek, V.; Turnovcova, K.; Sykova, E. Fluorescent magnetic nanoparticles for biomedical applications. J. Mater. Chem. 2011, 21, 7630-7639. [CrossRef]

27. Zhang, R.C.; Liu, L.; Xu, X.L. Synthesis and characteristics of multifunctional $\mathrm{Fe}_{3} \mathrm{O}_{4}-\mathrm{SiO}_{2}-\mathrm{CdS}$ magnetic-fluorescent nanocomposites. Chin. Phys. B 2011, 20,1-4.

28. Wu, X.; Zhang, Y.; Han, T.; Wu, H.; Guo, S.; Zhang, J. Composite of graphene quantum dots and $\mathrm{Fe}_{3} \mathrm{O}_{4}$ nanoparticles: Peroxidase activity and application in phenolic compound removal. RSC Adv. 2014, 4, 3299-3305. [CrossRef]

29. Bhattacharya, K.; Deb, P. Hybrid nanostructured C-dot decorated $\mathrm{Fe}_{3} \mathrm{O}_{4}$ electrode materials for superior electrochemical energy storage performance. Dalton Trans. 2015, 44, 9221-9229. [CrossRef]

30. Gavalas, S.; Kelarakis, A. Towards red-emissive carbon dots based systems. Nanomaterials 2021, 11, 2089. [CrossRef]

31. Kelarakis, A. From highly graphitic to amorphous carbon dots: A critical review. MRS Energy Sustain. 2014, 1, E2. [CrossRef]

32. Kelarakis, A. Graphene quantum dots: In the crossroad of graphene, quantum dots and carbogenic nanoparticles. Curr. Opin. Colloid Interface Sci. 2015, 20, 354-361. [CrossRef]

33. Wang, H.; Shen, J.; Li, Y.; Wei, Z.; Cao, G.; Gai, Z.; Hong, K.; Banerjeea, P.; Zhou, S. Magnetic iron oxide-fluorescent carbon dots integrated nanoparticles for dual-modal imaging, near-infrared light-responsive drug carrier and photothermal therapy. Biomater. Sci. 2014, 2, 915-923. [CrossRef] [PubMed]

34. Zhuo, S.; Guan, Y.; Li, H.; Fang, J.; Zhang, P.; Du, J.; Zhu, C. Facile fabrication of fluorescent Fe-doped carbon quantum dots for dopamine sensing and bioimaging application. Analyst 2019, 144, 656-662. [CrossRef] [PubMed]

35. Han, C.; Zhang, A.; Kong, Y.; Yu, N.; Xie, T.; Dou, B.; Li, K.; Wang, Y.; Li, J.; Xu, K. Multifunctional iron oxide-carbon hybrid nanoparticles for targeted fluorescent/MR dual-modal imaging and detection of breast cancer cells. Anal. Chim. Acta 2019, 1067, 115-128. [CrossRef] [PubMed]

36. Ahmadian-Fard-Fini, S.; Salavati-Niasari, M.; Ghanbari, D. Hydrothermal green synthesis of magnetic $\mathrm{Fe}_{3} \mathrm{O}_{4}$-carbon dots by lemon and grape fruit extracts and as a photoluminescence sensor for detecting of E. coli bacteria. Spectrochim. Acta A Mol. Biomol. Spectrosc. 2018, 203, 481-493. [CrossRef]

37. Dong, X.; AlAwak, M.; Tomlinson, N.; Tang, Y.; Sun, Y.P.; Yang, L. Antibacterial effects of carbon dots in combination with other antimicrobial reagents. PLoS ONE 2017, 12, e0185324. [CrossRef]

38. Guo, Y.; Tang, D.; Zhang, L.; Li, B.; Iqbal, A.; Liu, W.; Qin, W. Synthesis of ultrathin carbon dots-coated iron oxide nanocubes decorated with silver nanoparticles and their excellent catalytic properties. Ceram. Int. 2017, 43, 7311-7320. [CrossRef]

39. Liu, X.; Jiang, H.; Ye, J.; Zhao, C.; Gao, S.; Wu, C.; Li, C.; Li, J.; Wang, X. Nitrogen-Doped Carbon Quantum Dot Stabilized Magnetic Iron Oxide Nanoprobe for Fluorescence, Magnetic Resonance and Computed Tomography Triple-Modal In Vivo Bioimaging. Adv. Funct. Mater. 2016, 26, 8694-8706. [CrossRef]

40. Kumar, A.; Chowdhurni, A.R.; Laha, D.; Chandra, S.; Karmakar, P.; Sahu, S.K. One pot synthesis of carbon dots entrenched chitosan modified magnetic nanoparticles for fluorescence based $\mathrm{Cu}^{2+}$ ion sensing and cell imaging. RSC Adv. 2016, 6, 58979-58987. [CrossRef]

41. Lou, L.; Yu, K.; Zhang, Z.; Li, B.; Zhu, J.; Wang, Y.; Huanga, R. Functionalized magnetic-fluorescent hybrid nanoparticles for cell labelling. Nanoscale 2011, 3, 2315-2323. [CrossRef] [PubMed]

42. Zhang, S.; Niu, H.; Hu, Z.; Cai, Y.; Shi, Y. Preparation of carbon coated $\mathrm{Fe}_{3} \mathrm{O}_{4}$ nanoparticles and their application for solid-phase extraction of polycyclic aromatic hydrocarbons from environmental water samples. J. Chromatogr. A 2010, 1217, 4757-4764. [CrossRef]

43. Wang, M.; Fu, Q.; Zhang, K.; Wan, Y.; Wang, L.; Gao, M.; Xia, Z.; Gao, D. A magnetic and carbon dot based molecularly imprinted composite for fluorometric detection of 2,4,6-trinitrophenol0. Microchim. Acta 2019, 186, 86.

44. Wang, Z.; Guo, H.; Yu, Y.; He, N. Synthesis and characterization of a novel magnetic carrier with its composition of Fe $\mathrm{O}_{4} / \mathrm{carbon}$ using hydrothermal reaction. J. Magn. Magn. Mater. 2006, 302, 397-404. [CrossRef]

45. Krysmann, M.J.; Kelarakis, A.; Dallas, P.; Giannelis, E.P. Formation mechanism of carbogenic nanoparticles with dual photoluminescence emission. J. Am. Chem. Soc. 2012, 134, 747-750. [CrossRef] [PubMed]

46. Petricek, V.; Dusek, M.; Palatinus, L. Crystallographic computing system jana2006: General features. Z. Krist.—Cryst. Mater. 2014, 229, 345. [CrossRef]

47. Gamża, M.B.; Abrami, P.; Gammond, L.V.D.; Ayres, J.; Osmond, I.; Muramatsu, T.; Armstrong, R.; Perryman, H.; Daisenberger, D.; Das, S.; et al. Pressure-induced reconstructive phase transition in $\mathrm{Cd}_{3} \mathrm{As}_{2}$. Phys. Rev. Mater. 2021, 5, 024209. [CrossRef]

48. Gibbons, E.N.; Winder, C.; Barron, E.; Fernandes, D.; Krysmann, M.J.; Kelarakis, A.; Parry, A.V.S.; Yeates, S.G. Layer by Layer Antimicrobial Coatings Based onNafion, Lysozyme, and Chitosan. Nanomaterials 2019, 9, 1563. [CrossRef]

49. Li, B.; Wang, X.; Guo, Y.; Iqbal, A.; Dong, Y.; Li, W.; Liu, W.; Qin, W.; Chen, S.; Zhou, X.; et al. One-pot synthesis of polyamines improved magnetism and fluorescence $\mathrm{Fe}_{3} \mathrm{O}_{4}$-carbon dots hybrid NPs for dual modal imaging. Dalton Trans. 2016, 45, 5484-5491. [CrossRef] 
50. Tiwari, A.; Verma, N.C.; Turrkan, S.; Debnath, A.; Singh, S.; Draeger, G.; Nandi, C.K.; Randhawa, J.K. Graphitic Carbon Coated Magnetite Nanoparticles for Dual-Mode Imaging and Hyperthermia. ACS Appl. Nano Mater. 2019, 3, 896-904. [CrossRef]

51. Hu, F.; Wei, L.; Zhou, Z.; Ran, Y.; Li, Z.; Gao, M. Preparation of Biocompatible Magnetite Nanocrystals for In Vivo Magnetic Resonance Detection of Cancer. Adv. Mater. 2006, 18, 2553-2556. [CrossRef]

52. Wang, J.; Zhang, B.; Wang, L.; Wang, M.; Gao, F. One-pot synthesis of water-soluble superparamagnetic iron oxide nanoparticles and their MRI contrast effects in the mouse brains. Mater. Sci. Eng. C 2015, 48, 416-423. [CrossRef]

53. Kolhatkar, A.G.; Jamison, A.C.; Litvinov, D.; Willson, R.C.; Lee, T.R. Tuning the Magnetic Properties of Nanoparticles. Int. J. Mol. Sci. 2013, 14, 15977-16009. [CrossRef] [PubMed]

54. Knobel, M.; Nunes, W.C.; Socolovsky, L.M.; De Biasi, E.; Vargas, J.M.; Denardin, J.C. Superparamagnetism and Other Magnetic Features in Granular Materials: A Review on Ideal and Real Systems. J. Nano. Nanotech. 2008, 8, 2836-2857. [CrossRef]

55. Cullity, B.D.; Graham, C.D. Introduction to Magnetic Materials, 2nd ed.; Wiley-IEEE Press: Hoboken, NJ, USA, 2009 ; Volume 2.

56. Goya, G.F.; Berquó, T.S.; Fonseca, F.C.; Morales, M.P. Static and dynamic magnetic properties of spherical magnetite nanoparticles. J. Appl. Phys. 2003, 94, 3520. [CrossRef]

57. Martnez, B.; Obradors, X.; Balcells, L.; Rouanet, A.; Monty, C. Low Temperature Surface Spin-Glass Transition in $\gamma-\mathrm{Fe}_{2} \mathrm{O}_{3}$ Nanoparticles. Phys. Rev. Lett. 1998, 80, 181-184. [CrossRef]

58. Mercante, L.A.; Melo, W.W.M.; Granada, M.; Troiani, H.E.; Macedo, W.A.A.; Ardison, J.D.; Vaz, M.G.F.; Novak, M.A. Magnetic properties of nanoscale crystalline maghemite obtained by a new synthetic route. J. Magn. Magn. Mater. 2012, 324, $3029-3033$. [CrossRef]

59. Coey, J.M.D. Noncollinear Spin Arrangement in Ultrafine Ferrimagnetic Crystallites. Phys. Rev. Lett. 1971, 27, 1970-1972. [CrossRef]

60. Iglesias, Ò.; Labarta, A. Finite-size and surface effects in maghemite nanoparticles: Monte Carlo simulations. Phys. Rev. B 2001, 63, 184416. [CrossRef]

61. Dutta, P.; Pal, S.; Seehra, M.S.; Shah, N.; Huffman, P.G. Size dependence of magnetic parameters and surface disorder in magnetite nanoparticle. J. Appl. Phys. 2009, 105, 07B501. [CrossRef]

62. Phan, M.H.; Alonso, J.; Khurshid, H.; Lampen-Kelley, P.; Chandra, S.; Repa, K.S.; Nemati, Z.; Das, R.; Iglesias, Ó.; Srikanth, H. Exchange bias effects in iron oxide-based nanoparticle system. Nanomaterials 2016, 6, 221. [CrossRef] [PubMed]

63. Demortière, A.; Panissod, P.; Pichon, B.P.; Pourroy, G.; Guillon, D.; Donnio, B.; Bégin-Colin, S. Size-dependent properties of magnetic iron oxidenanocrystals. Nanoscale 2011, 3, 225-232. [CrossRef]

64. Kachkachi, H.; Ezzir, A.; Nogués, M.; Tronc, E. Surface effects in nanoparticles: Application to maghemite $\gamma-\mathrm{Fe}_{2} \mathrm{O}_{3}$. Eur. Phys. J. B 2000, 14, 681. [CrossRef]

65. Shendruk, T.N.; Desaultes, R.S.; Southern, B.W.; van Lierop, J. The effect of surface spin disorder on the magnetism of $\gamma$-Fe ${ }_{2} \mathrm{O}_{3}$ nanoparticle dispersions. Nanotechnology 2007, 18, 455704. [CrossRef]

66. Aquino, R.; Depeyrot, J.; Sousa, M.H.; Tourinho, F.A.; Dubois, E.; Perzynski, R. Magnetization temperature dependence and freezing of surface spins in magnetic fluids based on ferrite nanoparticles. Phys. Rev. B 2005, 72, 184435. [CrossRef]

67. Desautels, R.D.; Skoropata, E.; Chen, Y.Y.; Ouyang, H.; Freeland, J.W.; van Lierop, J. Increased surface spin stability in $\gamma$-Fe ${ }_{2} \mathrm{O}_{3}$ nanoparticles with a Cu shell. J. Phys. Condens. Matter 2012, 24, 146001. [CrossRef]

68. Rani, S.; Varma, G.D. Superparamagnetism and metamagnetic transition in $\mathrm{Fe}_{3} \mathrm{O}_{4}$ nanoparticles synthesized via co-precipitation method at different pH. Phys. B Condens. Matter 2015, 472, 66. [CrossRef]

69. Hu, Y.; Wang, P.; Bunker, C.E.; Teisl, L.R.; Reibold, M.; Yan, S.; Qian, H.; Hea, D.; Sun, Y.P. Preparation and optical properties of magnetic carbon/iron oxide hybrid dots. RSC Adv. 2017, 7, 41304-41310. [CrossRef]

70. Fan, R.J.; Sun, Q.; Zhang, L.; Zhang, Y.; Lu, A.H. Photoluminescent carbon dots directly derived from polyethylene glycol and their application for cellular imaging. Carbon 2014, 71, 87-93. [CrossRef]

71. Fernandes, D.; Heslop, K.A.; Kelarakis, A.; Krysmann, M.J.; Estevez, L. In situ generation of carbon dots within a polymer matrix. Polymer 2020, 188, 122159. [CrossRef]

72. Ding, H.; Zhou, X.X.; Wei, J.S.; Li, X.B.; Qin, B.T.; Chen, X.B.; Xiong, H.M. Carbon dots with red/near-infrared emissions and their intrinsic merits for biomedical applications. Carbon 2020, 167, 322-344. [CrossRef]

73. Berezin, M.Y.; Achilefu, S. Fluorescence Lifetime Measurements and Biological Imaging. Chem. Rev. 2010, 110, 2641-2684. [CrossRef] [PubMed]

74. Magrez, A.; Kasas, S.; Salicio, V.; Pasquier, N.; Seo, J.W.; Celio, M.; Catsicas, S.; Schwaller, B.; Forró, F. Cellular Toxicity of Carbon-Based Nanomaterials. Nano Lett. 2006, 6, 1121-1125. [CrossRef]

75. Yang, S.T.; Cao, L.; Luo, P.G.; Lu, F.; Wang, X.; Wang, H.; Meziani, M.J.; Liu, Y.; Qi, G.; Sun, Y.P. Carbon Dots for Optical Imaging in Vivo. J. Am. Chem. Soc. 2009, 131, 11308-11309. [CrossRef] [PubMed]

76. Patil, U.S.; AdireDdy, S.; Jaiswal, A.; Mandava, S.; Lee, B.R.; Chrisey, D.B. In Vitro/In Vivo Toxicity Evaluation and Quantification of Iron Oxide Nanoparticle. Int. J. Mol. Sci. 2015, 16, 24417-24450. [CrossRef]

77. Li, L.; Mak, K.Y.; Shi, J.; Koon, H.K.; Leung, C.H.; Wong, C.M.; Leung, C.W.; Mak, C.S.K.; Chan, N.M.M.; Zhong, W.; et al Comparative In Vitro Cytotoxicity Study on Uncoated Magnetic Nanoparticles: Effects on Cell Viability, Cell Morphology, and Cellular Uptake. J. Nanosci. Nanotechnol. 2012, 12, 9010-9017. [CrossRef] 
78. Stachowska, J.D.; Murphy, A.; Fernandes, D.; Gibbons, E.N.; Krysmann, M.J.; Kelarakis, A.; Burgaz, E.; Moore, J.; Yeates, S.G. A rich gallery of carbon dots based photoluminescent suspensions and powders derived by citric acid/urea. Sci. Rep. 2021, 11, 10554. [CrossRef]

79. Azam, A.; Ahmed, A.S.; Oyes, M.; Khan, M.S.; Habib, S.S.; Memic, A. Antimicrobial activity of metal oxide nanoparticles against Gram-positive and Gram-negative bacteria: A comparative study. Int. J. Nanomed. 2012, 7, 6003-6009. [CrossRef]

80. Anand, A.; Unnikrishnan, B.; Wei, S.C.; Chou, C.P.; Zhang, L.Z.; Huang, C.C. Graphene oxide and carbon dots as broad-spectrum antimicrobial agents-A minireview. Nanoscale Horiz. 2019, 4, 117-137. [CrossRef]

81. Huang, K.C.; Shieh, D.B.; Yeh, C.S.; Wu, P.C. Antimicrobial Applications of Water-Dispersible Magnetic Nanoparticles in Biomedicine. Curr. Med. Chem. 2014, 21, 3312-3322. [CrossRef] 